\title{
Coming of Age in America: The Misapplication of Sex-Offender Registration and Community- Notification Laws to Juveniles
}

\author{
Elizabeth Garfinkle $\dagger$
}

Since 1996, every state has enacted legislation requiring certain sex offenders to register with law enforcement and have their personal information available to the community, often for life ("Megan's Laws"). Slightly over half of all states require registration and community notification for juveniles adjudicated delinquent of sex offenses. This inclusion is a marked departure from the traditional juvenile justice system of maintaining separate procedures and consequences fö̈ juveniles and adults. In treating juveniles like adults under Megan's Laws, states have failed to consider the distinct characteristics of juvenile sex offending, such as the exceptionally low recidivism rate and culpability complications arising from age-of-consent laws. This Comment argues that applying communitynotification requirements to juvenile sex offenders is an ineffective tool for preventing future offenses but rather creates new harms for the very children the laws claim to protect.

\section{INTRODUCTION}

In all fifty states, people convicted of sex offenses and certain crimes against minors are required to register with law enforcement upon release from custody. Since enactment of the federal Megan's Law in 1996, states must implement some form of sex- and child-offender registration and community-notification legislation in order to receive $10 \%$ of federal

Copyright $(2003$ California Law Review, Inc. California Law Review, Inc. (CLR) is a California nonprofit corporation. CLR and the authors are solely responsible for the content of their publications.

$\dagger$ J.D. Candidate, School of Law, University of California, Berkeley (Boalt Hall), 2003. 1 would like to give special thanks to Professor Franklin Zimring for his inspiration, insight, and wit throughout the many stages of this project. I would also like to thank Donna Maeda, Sarah Abbott, Gabriela Gallegos, and other members of the California Law Review for their time, support, and editorial wisdom in preparing this Comment for publication. This Comment is dedicated to the memory of my mother, Suzi, who understood about kids. 
anticrime funds. ${ }^{1}$ While almost all felony convictions engender infringements on the released individuals' rights and opportunities, no other type of offense results in such pervasive postrelease requirements as do sexual offenses, particularly those perpetrated against minors. In a misguided effort to protect potential child and adolescent victims from the special crime of sexual assault, many states require registration and notification for child and adolescent offenders who have traditionally been viewed as needing special protections themselves.

This Comment examines the dangerous inconsistencies inherent in the state and federal applications of registration and community-notification laws to juveniles as compared to the rationales behind those laws and the theories and practices of the juvenile justice system. It then proposes changes and legal challenges to the existing laws. In so doing, this Comment argues that Megan's Laws are an inappropriate and ineffective means of preventing violent sexual offenses in general and that these problcms are magnified when the laws are applied to juveniles.

The Comment is organized into three main Parts: Part I generally examines the history, scope, and theoretical and rhetorical bases of Megan's Laws. Part II examines the scope and application of Megan's Laws to juveniles. This Part also demonstrates how juvenile sex offending is substantially different from adult sex offending and how adult-modelcd policies, such as community notification, are particularly harmful and ineffective when applied to juveniles. Part III offers policy changes and proposes legal challenges to the application of Megan's Laws to juveniles.

\section{What ARE MEgan's LaWs?}

\section{A. The History of Sex-Offender Registration and Community-Notification Laws}

Sex-offender registration laws existed in five states by 1986 and in almost half of all states by $1993 .^{2}$ However, most of those laws limited the release of registration information to law-enforcement agencies to facilitate

1. 42 U.S.C. $\$ 14071$ (2000). There are actually three laws. Enacted in 1994, the Jacob Wetterling Crimes Against Children and Sexually Violent Offenders Registration Act required registration and suggested community notification. Pub. L. No. 103-222, 108 Stat. 2038 (1994). In 1996, Congress added two additional laws. The first, called Megan's Law, required community notification. Pub. L. No. 104-145, 110 Stat. 1345 (1996). The other law created a federal database of registration information. Pub. L. No. 104-236, 110 Stat. 3093 (codified at 42 U.S.C. $\S 14072$ (2000)). See generally Daniel M. Filler, Making the Case for Megan's Law: A Study in Legislative Rhetoric, 76 IND. L.J. 315, 327 (2001).

2. Michele L. Earl-Hubbard, The Child Sex Offender Registration Laws: The Punishment, Liberty Deprivation, and Unintended Results Associated with the Scarlet Letter Laws of the 1990s, 90 NW. U. L. REV. 788, 790 n.7 (1996). For example, California has had some form of registration requirement for sex offenders for more than half a century. Abril R. Bedarf, Comment, Examining Sex Offender Community Notification Lasws, 83 CALIF. L. Rev. 885, 887 n.4 (1995). 
the location of suspects when new crimes occurred. ${ }^{3}$ Then, in the wake of several high-profile child-rape and murder cases in the early 1990s, the nature, purpose, and impact of sex-registration laws changed.

In I989, Westley Dodd abducted and killed two young brothers after raping one of them. ${ }^{4} \mathrm{~A}$ month later, Dodd molested and killed another young boy. ${ }^{5}$ Horrified by Dodd's claim that if released he would rape and kill again and enjoy it, the state of Washington, in the first legal hanging in the United States since 1965, executed Dodd. ${ }^{6}$ Then, in 1990, a seven-yearold Tacoma boy was found wandering in the woods in shock and covered in mud and blood. Earl Shriner, who had a long prior record of sexual offenses and assaults, had raped the boy, stabbed him, cut off his penis, and left him to die.?

The horribly brutal attacks on these young boys and the sordid records of their perpetrators saturated the Washington media in 1989 and $1990 .^{8} \mathrm{~A}$ scared and outraged public successfully lobbied the Washington legislature for community notification as a citizen's tool for protecting the state's children. ${ }^{9}$ On the wings of the increasingly powerful victim's rights movement, ${ }^{10}$ Washington's sex-offender registration and community-notification law flew through the legislature in $1990 .{ }^{11}$ The act was the first of many to require law enforcement to release and disseminate the registration information when "relevant ... [and] . . . neccssary to protect the publie."12 Procedures for sex-offender information dissemination in Washington vary by county, and they have included flyering mailboxes and bulletin boards, as well as routine community notification whenever any registered sex offender is released from custody. ${ }^{13}$

Washington state's novel approach paved the way for other states to experiment with community-notification requirements. For example, one of Louisiana's community-notification requirements takes the unusual form of having the registrant personally identify himself or herself to the community. ${ }^{14}$ The 1992 statute requires the registrant to personally notify all persons within a designated area and to publish his or her name,

3. See Bedarf, supra note 2, at 888 .

4. W. Paul Koenig, Does Congress Abuse Its Spending Clause Power by Attaching Conditions on the Receipt of Federal Law Enforcement Funds to a State's Compliance with "Megan's Law"?, 88 J. Crim. L. \& Criminology 721, 723-24 (1998).

5. Id.

6. Id.

7. Earl-Hubbard, supra note 2, at 794.

8. Id.

9. Id.

10. Jonathan Simon, Megan's Law: Crime and Democracy in Late Modern America, 25 LAW \& Soc. INQUIRY. I $111,1136(2000)$.

11. Earl-Hubbard, supra note 2, at 794.

I2. 42 U.S.C. § I $4071($ e)(2) (2000); WASH. REv. CODE § 4.24.550(1) (2003).

13. Earl-Hubbard, supra note 2, at 810 n.149-51.

14. La. Rev. Stat. ANN. § 15.542 (2001). 
address, and crime in a local newspaper within thirty days of moving to a new area. ${ }^{15}$ While no other states have yet adopted Louisiana's proactive approach, ${ }^{16}$ Washington's version of community notification was soon launched from Capitol Hill as a national model.

On July 29, 1994, Jesse Timmendequas, who had twice been convicted of sexual offenses against children, raped and murdered his neighbor, a seven-year-old New Jersey girl named Megan Kanka. ${ }^{17}$ Claiming that her daughter would still be alive if she had known about her neighbor's history of sexual offenses, Megan's mother, and thousands of supporters implored the New Jersey legislature to help citizens identify sexual offenders in their neighborhoods. ${ }^{18}$ The legislature acted quickly. On October 31, 1994, New Jersey Governor Christine Todd Whitman signed the first piece of legislation bearing the name "Megan's Law."19

Meanwhile, by 1993, Congress had begun debating the first of three sex-registration laws that states would have to adhere to in order to receive their share of about $\$ 100$ million of federal crime-prevention funds. ${ }^{20}$ Forming part of the Violent Crime Control and Law Enforcement Act of 1994 (the "1994 Act"), ${ }^{21}$ the Jacob Wetterling Crimes Against Children and Sexually Violent Offenders Registration Act (the "Wetterling Act") required registration for a wide array of sexual offenses perpetrated against both adults and children as well as some nonsexual offenses against children, such as kidnapping. ${ }^{22}$ The Wetterling Act permitted states to give law-enforccment authorities discretion in allowing for community notification when necessary to protect the public, but did not require it. ${ }^{23}$

15. Id.

16. Id. The statute requires that the adult offender shall

[g]ive notice of the crime for which he was convicted, his name, address, and a photograph or copy thereof to: (a) At least one person in every residencc or business within a onc-mile radius in a rural area and a three-tenths of a mile radius in an urban or suburban area of the address where the defondant will reside upon release.

Id.

17. Koenig, supra note 4, at 721 .

18. Simon, supra note 10 , at 1128.

19. N.J. STAT. ANN. §§ 2C:7-1-2C:7-17 (West 2001); Filler, supra note 1, at 315. This Comment uses the term "Megan's Laws" throughout to refer generally to both federal and state registration and notification laws.

20. Earl-Hubbard, supra note 2, at 796; Filler, supra note 1, at 327 . In addition to the crime prevention incentive, states that enact Megan's Laws are eligible for special grants to cover some of the costs of administering the laws. For a look at Spending Clause challenges to federal Megan's Laws, see Simon, supra note 10.

21. Pub. L. No. 103-222, 108 Stat. 2038 (1994)

22. Jacob Wetterling Crimes Against Children and Sexually Violent Offender Registration Program (codified as amended at 42 U.S.C. $\$ 14071$ (2000)); see also Filler, supra note 1, at 327.

23. Filler, supra note 1 , at 327. 
Concerned that some law-enforcement agencies were "still reluctant" to release information, ${ }^{24}$ Congress amended the Wetterling Act in 1996 to change the wording from "may release" to "shall release" 25 "so that all 50 States [would] be held to a common standard of community notification." 26 Congress also amended the 1994 Act to allow registration information to be distributed for any purpose permitted by state law and, under the authorship of New Jersey Representative Zimmer ${ }^{27}$ renamed the Act "Megan's Law." ${ }^{28}$ Later that year, Congress enacted a third law, the Pam Lyncher Sexual Offender Tracking and Identification Act of 1996, creating a federal database of registration information. ${ }^{29}$ Most recently, in 2000, Congress added a requirement that registrants report their enrollment or employment at institutions of higher education. ${ }^{30}$

Every state legislature had passed a sex-offender registration law with a community-notification component by the end of $1996 .{ }^{31}$ The federal Megan's Law now provides a baseline of who has to register and for what kinds of crimes, but allows states to expand upon the federal suggestions. As a result, there are substantial differences in the scope and impact of sexregistration statutes throughout the fifty states.

For example, the kinds of offenses that trigger registration vary from state to state. The offenses listed in the federal statute, which are to serve as a nonexclusive guideline, include kidnapping or false imprisonment of a minor, any type of sexual offense against a minor, and sexually violent offenses against adults and children. ${ }^{32}$ While the duration of registration under the federal statute is ten years or life, depending on the nature of the conviction, durations under state statutes vary. ${ }^{33}$ Additionally, although the federal Megan's Law requires that states enact some sort of communitynotification requirement to get specified funding, the federal statute does not dictate what that notification should look like. Rather, state law-enforcement agencics have discretion to determine the "relevant

24. Elizabeth Rahmberg Walsh \& Fred Cohen, Sex Offender Registration and Community Notification: A “Megan's Law" Sourcebook 6-10 (quoting Rep. McCollum, 142 Cong. Rec. H4452 (daily ed. May 7, 1996) (statement of Rep. McCollum)).

25. Id. at $\mathbf{H} 4452$ (statement of Rep. McCollum).

26. Id. at $\mathrm{H} 4453$ (statement of Rep. Zimmer).

27. Id. at $\mathbf{H} 4452$ (noting introduction of bill by Rep. Zimmer).

28. Id. at $\mathrm{H} 4451$.

29. 42 U.S.C. § 14072 ; Filler, supra note 1 , at 327.

30. 42 U.S.C. $\$ 14071(2000)$.

31. WALSH \& COHEN, supra note 24 , at 1-1.

32. 42 U.S.C. $\$ 14071$ (a) (2000)

33. Id. $\S 14701(\mathrm{~b})(6)$. Most states require lifetime registration for all or some offenses. For cxample, California requires lifetime registration for all offences but allows petition for rehearing every ten years, CAL. PEN. CODE $\$ 290$ (a)(1) (West 2002); Alaska requires fifteen years for singlc offense and lifetimc for aggravated or multiple offenses, ALASKA ADMIN. CODE $\$$ 12.63.020(a)(1)-(2) (2000). 
information" and the method of notification that are "necessary to protect the public." 34

\section{$B \quad$ The Rhetoric and Rationales Behind Megan's Laws}

Community-notification laws have been enacted exceptionally quickly throughout the country. While the federal requirement for community notification was added two years after the initial registration bill, which merely had allowed for notification, there was very little legislative debate over the amendment, and the final vote in favor of it was unanimous. ${ }^{35}$ Such unilateral support is remarkable given that Megan's Laws have met with substantial criticism in much of the legal world ${ }^{36}$ Why were Mcgan's Laws so politically appealing despite their substantial attacks on basic liberties? An examination of the limited legislative debate both in Congress and in the state legislatures provides an informative look at the possible intent of the lawmakers, the theories behind Megan's Laws, and the political forces that pushed them through. In addition, some of the statutes include "Findings" sections, which give an indication of the theories relied upon in enacting the laws.

\section{Playing on Emotions Through Rhetorical Techniques}

Megan's Laws, like other recidivist policies, are premised more on emotional sentiments such as disgust, morality, and fear, than on rational assessments of crime reduction. ${ }^{37}$ Thus, before examining the theories behind community notification, which were generally unquestioned by the lawmakers, it is worthwhile to note the rhetorical techniques invoked by legislators that played on such emotions in rallying the unanimous support for Megan's Laws. In an analysis of the legislative debates of Megan's Laws in both the U.S. Congress and in the New York legislature, Daniel M. Filler locates three main rhetorical techniques: the use of compelling narratives, the use of shocking statistics, and the dehumanization of those affected by the legislation.

\section{a. Narratives}

In arguing for support of Megan's Law, lawmakers told and retold minutely detailed stories of the horrible attacks on Megan Kanka and other young children. For example, California Senator Feinstein described how Polly Klaas had been "kidnapped from her bedroom on October 1, 1993,

34. 42 U.S.C. $\& 14071(\mathrm{e})(2000)$.

35. WALSH \& COHEN, supra note 24 , at 6-24.

36. Filler, supra note 1, at 318 .

37. See generally Mona Lynch, Pedophiles and Cyber-Predators as Contaminating Forces: The Language of Disgust, Pollution, and Boundary Invasions in Federal Debates on Sex Offender Legislation, 27 LAW AND SOC. INQUIRY 529 (2002). 
by a bearded, knife-wielding man who tied her up and threatened to slit her friends' throats as her mother slept in a nearby room ...." ${ }^{38}$ Filler gives several explanations for why lawmakers tell stories in their speeches. For one, stories, and in particular gory crime stories, have tremendous societal appeal and are easier to remember than logic-based claims. ${ }^{39}$ Politicians hoping to make the evening news or catch a C-SPAN viewer's attention are wise to tell an engrossing story. Also, by linking the debated legislation with a famous crime, legislators perform what Filler calls "legally permissible retribution against sex offenders." ${ }^{40}$ While state Megan's Laws can not be overtly punitive if they are to survive the Ex Post Facto Clause of the Constitution, ${ }^{41}$ linking a distasteful requirement to specific crimes through narrative satisfies a thirst for retribution felt by many of those who hear the tale. Telling stories also situates the law and the crime in a palatable way, so that Megan's Laws become the satisfying final chapter of Megan's tragic death. ${ }^{42}$

\section{b. Unsupported Statistical Claims}

Second, Filler examines the rhetorical technique of using unsupported and misused statistical claims. ${ }^{43}$ For example, to support his claim for the need for community notification, Minnesota Representative Ramstad cited a study which claimed that 114,600 cases of attempted abduction and 4,600 cases of actual abduction occurred in $1988 .{ }^{44}$ But, as Filler points out, Ramstad did not acknowledge that the authors of the study had stressed

38. Filler, supra note 1 , at 331.

39. Id. at 348 .

40. Id.

41. See Doe I v. Otte, 259 F.3d 979, 994 (9th Cir. 2001) (finding that Alaska's communitynotification requirements, codified in ALASKA ADMIN. CODE tit. I3, $\S 09.050$ (a) (2000), were punitive because of the substantial and excessive disability imposed in relation to the code's nonpunitive purposes). The Ninth Circuit held that applying the punitive requirements to persons convicted of crimes before the enaetment of the eode violated the Ex Post Facto Clause of the Constitution, U.S. Const. art. 1, § 10. Otte, 259 F.3d at 995. "The Ex Post Facto Clause prohibits states from enacting any law that 'changes the punishment, and inflicts a greater punishment, than the law annexed to the crime, when committed."' Id. at 984-85 (citing Calder v. Bull, 3 U.S. 386, 391 (1798)).

42. Filler, supra note 1, at 350. Indeed, one of the most impassioned pleas madc in support of Megan's Law was that it would give meaning to Megan's short life. As New Jersey Representative Martini admonished his fellow Iawmakers, "[w]e must not allow this little girl's life to be taken in vain.” 142 CONG. REC. E732 (daily ed. May 8, 1996) (statement of Rep. Martini). Similar arguments were made at the state level as well. In response to the murder and sexual assault of a nine-year-old girl, the Texas legislature named a sex-offender law "The Amber Hagerman Protection Act," despite the impossibility of any law being able to protect Amber at that point. Lynch, supra note 37, at 27. 1t is worth noting that children die every day in America from causes ranging from hunger, to accidents, to violent abuse. Not every child can have a major alteration to the criminal justice system named after him or her, and most people aecept this. The fact that immortalizing Megan Kanka was urged by Iawmakers as a reason for mandating community notification indicates the glaring absence of rational debate surrounding the enactment of Megan's Law.

43. Filler, supra note 1 , at 352.

44. Id. at 353 . 
that most of those abductions were brief and that the kinds of severe kidnappings that most people imagine when hearing the word (especially after hearing the legislative debates on Megan's Law) numbered only 200 to 400 nationwide. $^{45}$ Similarly, when Texas Representative Jackson-Lee cited 50,000 cases of child abuse and neglect, she did not point out that most of those incidences were not the kind of abuse that Megan Kanka had suffered, nor would they result in a sex-offense conviction that would require community notification under Megan's Law. ${ }^{46}$ Finally, legislators ignored the important statistic that only $3 \%$ of sexual abuse and $6 \%$ of child murders are committed by strangers. ${ }^{47}$ Accordingly, the vast majority of such offenses are committed by friends and relatives, which are crimes that Megan's Laws are not designed to prevent. ${ }^{48}$

\section{c. Dehumanization}

The third rhetorical technique cited by Filler is the dehumanization of the people most affected by Megan's Laws, the individuals whose personal information and criminal records will be subject to public scrutiny. For example, in referring to the release of Jesse Timmendequas after serving time for a prior offense, New York Representative Molinari stated, "The fact that he was released and allowed to roam the streets in and around young children, is nothing less than placing a wolf among lambs." ${ }^{, 49}$ A less blatant, but still powerful, example of dehumanization was used as a core term of the debate and the law itself. In federal and most state Megan's Laws, "sexually violent predator" refers to a specific category of persons subject to community notification for life. ${ }^{50}$ Thus, the origin of the term "predator," animals who must hunt prey in order to survive, becomes metaphorically inseparable from the legal category specially created for Megan's Laws. ${ }^{51}$ By diminishing the potential skeptic's ability to relate to the people most affected by community notification, lawmakers' use of the rhetorical tool of dehumanization makes the weak theoretical foundation proffered by the proponents of Megan's Laws appear more formidable.

45. Id. at 354 .

46. $\quad l d$. at 353 .

47. Lynch, supra note 37, at 545; see also infra Part I.A.2.b.

48. One can find other kinds of questionable number-crunching within the legislators' statistical claims. In an attempt to show that the current crime rate is unacceptably high, Representative McCollum calculated that 700 violcnt crimes per 100,000 Americans represents a $500 \%$ increase when compared to the 200 violent crimes per 100,000 Americans of thirty years ago. 142 CONG. REC. H4452 (daily ed. May 7, 1996) (statement of Rep. McCollum). While a 250\% inerease (the mathematically corrcct calculation, given these figures) may indeed be frightening, the Congressman's sloppy arithmetic calls any rcliancc on the authority of unsupported statistics into question.

49. Id. at $\mathrm{H} 4457$ (statement of Rep. Molinari).

50. 42 U.S.C. $\S I 4071($ b)(6)(B) (2000).

51. Filler, supra notc I, at 339. 


\section{Rationalizing that "Sexual Offenders Are Different"}

[T] here is no greater crime, I do not believe, than a child that has been molested, perhaps killed, or not killed but sexually molested by somebody else. ${ }^{53}$

While the bulk of the tragic stories told by legislators during debate featured the brutal murder of a young child, Megan's Laws focus on sex, not murder. The federal Megan's Law and the many state versions cover a fairly wide array of sex offenses. Some offenses are consensual and nonviolent, and many do not distinguish between adult and child victims and perpetrators. But the laws include only a few nonsexual offenses. For instance, kidnapping makes every list, but murder or nonsexual violent attacks on children and adults notably do not. The rationale that sex offenders are different and thus merit a distinct legal response was voiced by many lawmakers as the basis for needing community notification, with surprisingly little tangible explanation or support.

\section{a. The Recidivism Myth}

[S] exual offenders are different ... . Even after long, long years in prison... the odds are extremely high that they will commit the same or a similar crime again..$^{54}$

Legislators frequently claim that sex offenders are more likely to reoffend than other kinds of offenders. This claim has escaped challenge throughout the legislative debates, the texts of the laws themselves, and the responses to Megan's Laws, and one would assume that there must be an impressive array of studies and statistics forming the basis of the claim. For example, the "Legislative Findings" section of Pennsylvania's registration statute states that "sexually violent predators pose a high risk of engaging in further offenses even after being released from incarceration or commitments...."55 Similarly, the Oklahoma statute reads, "The Legislature finds that sex offenders who commit other predatory acts against children and persons who prey on others as a result of mental illness pose a high risk of reoffending after release from custody." 56 While the use of "predator" and "prey" as acceptable legal terms for describing human behavior is in itself noteworthy, ${ }^{57}$ it is the unsupported assumption of the high recidivism rate for sex offenders that warrants examination here.

\footnotetext{
52. 142 Cong. Rec. H4453 (daily ed. May 7, 1996) (statement of Rep. Schumer).

53. . Id. at H4456 (statement of Rep. Upton).

54. Id. at $\mathrm{H} 4452$ (statement of Rep. Schumer).

55. 42 PA. Cons. Stat. AnN. \$9791(a)(2) (2001).

56. 57 OKL. ST. ANN. tit. $57 \S 581$ (B) (2002).

57. See Filler, supra note 1, at 339; see also supra Part 1.B.1.c (discussing dehumanization
} teehniques). 
A closer look at the scholarly research reveals that almost all studies show a relatively low recidivism rate for sex offenses as opposed to other crimes. ${ }^{58}$ For example, a study published by the American Psychological Association found only a $13 \%$ average recidivism rate for sex offenses. ${ }^{59}$ In arguing that Megan's Laws are misguided and ineffective, American Civil Liberties Union president, Nadine Strossen, cited a National Center for Institutions and Alternatives metanalysis study of recidivism rates, which found that the recidivism rates of sex offenders are lower than any other category of offenders except murderers. ${ }^{60}$

Since statements by politicians get more coverage in the media and are more easily digestible than scholarly studies, their false statements of information can have a domino effect, influencing future policy decisions. Upon signing a 1997 act allowing chemical castration as a sentence for sex offending, California Governor Pete Wilson cited Department of Corrections statistics in claiming that "more than half of all paroled sex offenders will commit a new sex offense or parole violation less than a year after being released from prison, and that three out of four will commit a new offense or parole violation within two years." ${ }^{61}$ But in a thorough analysis of official Department of Corrections statistics, Professor Franklin Zimring could not find any study that reflected the Governor's numbers. ${ }^{62}$ A study of lewd-conduct convictions observed a $17 \%$ reoffending rate after one year and a $26 \%$ reoffending rate after two. ${ }^{63}$ In a California Department of Corrections study of a particularly high-risk group, $62 \%$ of the released sex offenders did return to prison within two years, but only $15 \%$ of those were back for committing a sex crime. ${ }^{64}$ Ironically, many of the other prison revisits were for failing to register under California's sex-registration law. ${ }^{65}$

While the specific percentages vary, in every study, the majority of sex offenders do not recidivate. Thus, contrary to lawmakers' claims, sex offenders are more likely to not pose a threat of another sex offense than

58. Franklin E. Zimring, The Truth About Repeat Sex Offenders, L.A. Times, May 5, 1997, at B5.

59. R. Karl Hanson \& Monique T. Bussière, Predicting Relapse: A Meta-Analysis of Sexual Offender Recidivism Studies, 66 J. Consulting \& CliniCal Psychol. 348, 357 (1998). The study's discussion noted that the rate may be an underestimate, given the underreporting of most sex offenses, but it stressed that sex-offender recidivism rates are indeed low, that no studies have found long-term rccidivism rates higher than $40 \%$, and that the low recidivism rates make risk-assessment methods for sex offenders difficult to construct.

60. Panel Discussion, Megan's Law and the Protection of the Child in the On-Line Age, 35 AM. CRIM. L. Rev. 1319, 1323 (1998).

61. Zimring, supra note 58.

62. Id.

63. Id.

64. Id.

65. Id. In California, the stakes are particularly high bccause failing to register can be a "strike," exponentially increasing the sentence under California's Three Strikes law. See People v. Gareia, 23 P.3d 590 (Cal. 200I). 
they are to reoffend. Yet Megan's Laws subject all registrants to the privacy burdens of community notification in an attempt to monitor the minority who will reoffend. Considering that California uses the recidivism myth to endorse chemical castration, and that three states recently have enacted statutes allowing for capital punishment for sex with a minor under twelve and other specified sex crimes, the risks of relying on false predictors of future dangers are significant indeed..$^{66}$ Reliance upon the recidivism myth becomes even more problematic when applied to juveniles, as will be discussed in Part II of this Comment.

\section{b. "Prey[ing] Upon the Most Vulnerable Segments of our Population"67}

The law is especially ferocious in maintaining the boundary between childhood "innocence" and "adult sexuality. "68

In listening to story after story of horrible child-rapes and murders in the legislative debates, the observer is left with no other picture of what actually constitutes the many sexual offenses triggering registration. According to the rhetoric of Megan's Laws supporters, sex offenders are different because they are animals who prey upon vulnerable children. The only lawmaker to mention any other type of potential victim during the federal debates was Representative Dunn of Washington, who claimed that "women are the targets of most repeat sexual predators." ${ }^{19}$ But every other reference to sexual offenses involved a child victim to a brutal attack by a stranger.

Despite this emphasis on child victims in both the debates and the names of community-notification laws, the actual legislation includes more politically and morally ambivalent offenses perpetrated against adults, as well as offenders who are children and whose victims (or partners) are their age-peers. For example, most statutes include indecent exposure as a triggering offense, ${ }^{70}$ and displaying a sign or bumper sticker with "obscene language descriptive of sexual or excretory activities" triggers Alabama's Megan's law. ${ }^{71}$ In addition, the debates' focus on terrifying attacks by strangers addresses only a fraction of actual sexual-abuse incidents. As only $3 \%$ of sexual abuse and $6 \%$ of child murders are committed by strangers, Megan's Laws do remarkably little to protect children from the

66. Lynch, supra note 37 , at 537.

67. Panel Discussion, supra note 60, at 1322.

68. Gayle Rubin, Thinking Sex: Notes for a Radical Theory of the Politics of Sexuality, in Pleasure And Danger 290 (Carole Vance ed., 1989).

69. 142 ConG. ReC. H4457 (daily ed. May 7, 1996).

70. E.g., Ala. Code § 13a-11-200 (2001); CAL. Pen. Code $§ 290$ (1999)

71. ALA. CODE $\S 13 a-11-200(2001) ;$ id. $\S 13 a-12-131$. In the majority of states whose lewd- and lascivious-conduct laws include conduct between age-peers, even "playing doctor" could trigger registration. See infra note 114 and discussion in Part 11.C.1.a. 
most likely source of danger: friends and relatives. ${ }^{72}$ In fact, in at least one state, judges have discretion to not assign community notification when the victim is a minor relative or a cohabitating partner or spouse. ${ }^{73}$ Yet, a central theory behind the passage of Megan's Law is that by enacting community-notification laws, Congress is protecting children from the most dangerous offenders waiting to prey upon them. ${ }^{74}$

Filler posits that framing Megan's Law exclusively in terms of child protection makes political sense. ${ }^{75}$ Since most people view young children as innocent and vulnerable amidst a general population portrayed as horrifyingly violent on the evening news, child protection is a popular and timeless rallying point for politicians. As Filler puts it, "by asserting that [the] purpose [of Megan's Laws] was protecting children, supporters inoculated it from attack; no representative would go on the record against this goal." ${ }^{976}$ Indeed, representatives were quite blunt on this point. The words of Representative Molinari of California left little room for opposition: "For those of you who oppose the bill, I ask you to envision the loss of your child." ${ }^{\prime 77}$ Equating Megan's Law with child protection allowed the horrible thought of losing one's child to a violent stranger to override any concern with the scope or effectiveness of the act that lawmakers may have harbored.

\section{c. The Relative Disvalue of Sex Offenders' Constitutional Rights}

[P] erhaps a sexual predator's life should be just a little more toxic than someone else in the American citizenry, that an individual that preys on children, that maybe their rights should be secondary to children's and families '? ${ }^{78}$

Of the many people who spoke during the Housse debates on Megan's Law, only one voiced any reservations. ${ }^{79}$ After expressing his great reluctance to speak, given his understanding that sex offenders pose a higher

72. Lynch, supra note 37 , at 545 .

73. Ст. STAT. $\S 54-255(a)$, (b) (2001).

74. Filler, supra note 1 , at 355 . Filler locates different variations on the theme of terrifying dangers confronting our nation's children which have grabbed the political spotlight in each of the last four decades. In the 1960s, "The Battered Child Syndrome" gave voice to the still most prevalent danger facing children, child abuse. Id. at 357. In the 1970s, there was widespread panic over child pornography. $1 d$. In the 1980s, children's pictures on milk cartons reflected the growing concern with child abductions. $1 d$. And, finally in the 1990s, it was the danger created by anonymous sexual predators. Id.

75. Id. at 357 .

76. Id. at 358 .

77. 142 Cong. REC. H4457 (daily ed. May 7, 1996) (statement of Rep. Molinari).

78. Id. at $\mathrm{H} 4454$ (statement of Rep. Cunningham)

79. While another congressman, Representative Conyers, did note that courts have found notification to be punishment and thus Megan's Law may pose constitưtional issues, his strong support for the measure suggests that this caution does not rise to the level of a reservation. Id. at H4452 (statement of Rep. Conyers). 
risk of rccidivism, ${ }^{80}$ North Carolina Representative Watt raised two concerns with the proposal. First, he stated that the bill's underlying assumption that "once you have committed one crime of this kind, you are presumed guilty for the rest of your life ... is contrary to the constitutional mandates that govern our Nation." ${ }^{81}$ He argued that once sex offenders "have paid their debt to society, they should be allowed to go on with their lives." ${ }^{12}$ His second concern was one of federalism: Congress was attempting to unconstitutionally interfere in states' police powers. ${ }^{83}$ It is worth noting that, unlike the supporters of Megan's Law, Watt did not use any of the rhetorical tactics, such as narratives and statistics, described in Part I.B.I above.

The first argument by Representative Watt was generally dismissed by his colleagues with the kinds of statements quoted above. They urged him to balance the allegedly competing rights of convicted sex offenders like Jesse Timmendequas with those of innocent children like Megan Kanka. ${ }^{84}$ The federalist argument was side stepped almost entirely. Perhaps not wanting to go on record as having sided with sexual predators over innocent children, Representatives Watt and Scott (the only other dissenter) changed their votes to support the bill, thus allowing for a unanimous congressional vote in favor of Megan's Law. ${ }^{85}$

\section{d. Sex Is Different}

Long prison terms do not deter them. Too often, special rehabilitation programs do not cure them. No matter what we do, the minute they get back on the street, many of them resume their hunt for victims, beginning a restless and unrelenting prowl for children, innocent children to molest, abuse, and in the worst cases to kill. ${ }^{86}$

Throughout the legislative debates, sex offending was portrayed as an innate, immutable, personal identity, rather than as isolated acts for which individuals could be convicted and rehabilitated. Megan's Laws were heralded as a necessary departure from standard criminal-sentencing procedures for standard criminals in order to address the particular dangers of "pedophiles ... for whom we (as a society) have failed to come up with

80. Id. at $\mathrm{H} 4456$ (statement of Rep. Watt).

81. Id.

82. Id.

83. Id. For an interesting analysis of the potential violation of the Spending Clause by Megan's Laws, see generally Simon, supra note 10.

84. 142 CoNG. ReC. H4454 (daily ed. May 7, 1996).

85. While employing those techniques may not have been enough to rally support for his unpopular position, it might have more successfully engaged other members of Congress, especially given their familiarity with narratives and statistics.

86. 142 CONG. REC. H4453 (daily ed. May 7, 1996) (statement of Rep. Schumcr) 
anything that works." ${ }^{, 77}$ The understanding of sexuality as forming identities or psychoses is a dominant one in modern American culture. However, in The History of Sexuality, Michel Foucault examined how such shared understandings of sexuality are historically situated and thus constructed more by discourse than by a scientifically objective comprehension of human nature. ${ }^{88}$ In so arguing, Foucault describes how the conceptualization of homosexuality, for example, metamorphosed from a label for aberrant same-sex acts to a total personal identity. ${ }^{89}$ In much the same way, discourse surrounding sex offenders over the last century has transformed from interventions addressing isolated illicit, violent, or exploitative acts into strategies for combating an innate, polluting, psychosis that can be transferred to the innocent child victims. ${ }^{90}$

The fact that proponents of Megan's Law were so ready to accept the misrepresentation of recidivism risks and ignore constitutional concerns was fueled by this popularly held notion of sex offending as an innate, immutable, personal quality. If sex offending is an irreparable way of being, the lawmakers claimed or implied, then sex offenders must be monitored. However, since the empirical evidence suggests that sex offending is more likely than other kinds of offending to be an isolated event for an individual sex offender, rather than a psychosis or deviant personality trait, then Megan's Laws are a far less effective and palatable tool than the legislative debates would imply.

In much the same way that the notion of sex offending as an innate psychosis is socially constructed, the concept of sexual abuse as being especially harmful because it attacks childhood innocence and purity is constructed as well. ${ }^{91}$ This Comment does not dispute that many acts of sexual abuse are expressions of violence and power that wreck substantial and long-lasting harm upon the survivor. ${ }^{92}$ Nor does it dispute that many survivors of sexual abuse experience their abuse as being a particularly harmful attack on one's personhood, because of its sexual nature. ${ }^{93}$ Instead, it argues that the particularized harm assigned to sexual abuse is in itself a product of the shared discourse that labels all illicit sex as harmful.

87. Id. at $\mathrm{H} 4456$.

88. Michel Foucault, The History of Sexuality (1978).

89. Id. at 43 .

90. Michigan's "Findings" section claimed that persons convicted of a sex offense pose a "serious menace and danger to the ... morals ... of the people, and particularly the children, of this state." Mich. STAT. ANN. \$ 28.721 a (effective Oct. 1, 2002). See also Lynch, supra note 37.

91. See generally Lynch, supra note 37. See also Judith Levine, Harmful to Minors: The Perils of Protecting ChILdRen from Sex 45-67 (2002); Rubin, supra note 68.

92. Lynne H. Henderson, What Makes Rape a Crime?, 3 Berkeley Women's L.J. 193, 226 (1987-88).

93. Id. 
For example, shared American discourses, such as the enormous value assigned to maintaining childhood sexual innocence, ${ }^{94}$ or the historical situating of women as property, with chastity as their primary means of valuation, portray the crossing of culturally constructed sexual boundaries as an assault on one's personhood. ${ }^{95}$ But the fact that many experience sexual abuse as a particularized harm does not necessarily warrant its legal treatment as inherently more harmful than other forms of abuse. Five thousand children are killed and 18,000 are permanently disabled each year from child abuse, the vast majority of which is nonsexual and perpetrated by parents. ${ }^{96}$ However, sex crimes are the only ones considered threatening enough for a community notification requirement.

By making sexual abuse the ultimate crime, lawmakers essentialize all parties down to that single sexual experience. ${ }^{97}$ One party is assigned a lifetime identity as a dangerous sexual predator, and the other is assigned a lifetime identity of a victim who lost the one thing society valued the most, her innocence. This Comment argues that the very act of assigning particularized consequences to offenses merely because they are sexual, in itself reinforces the discourse that creates the particularized harm, thus magnifying the harm without actually mitigating the occurrence of abuse. As will be discussed in Part II, assigning lifetime identities based on a perceived attack on innocence becomes especially problematic when both the alleged perpetrator and victim are children.

\section{II}

The Application of Megan's Laws to Juveniles in Theory and Practice

\section{A. The Variations in States' Applications of Megan's Laws to Juveniles}

Although the federal legislative debates never mentioned juvenile sex offenders, the laws of twenty-eight states and the federal Megan's Law specifically require registration and community notification for juveniles adjudicated delinquent for certain crimes. ${ }^{98}$ The statutes of an additional

94. Rubin, supra note 68 at 268; see also 142 CoNG. Rec. H4451-H4457 (daily ed. May 7, 1996) (legislative rhetoric citing importance of proteeting innocence as reason for Megan's Law).

95. John D'Emilio \& Estelle B. Freedman, A History of Sexuality in America 79 (1988). Indeed, the loss of a woman's chastity has often been equated with death. Id. at 70 .

96. Elliot Currie, Crime and Punishment in America 82 (I998).

97. Treating sex crimes as worse than other forms of violence, including murder, reflects similar value systems as cultures that murder their rape victims because they have lost their chastity, and thus, their value to society.

98. See infra Appendix. Each of the following statutes specifically include juvenile adjudications to some extent. Parentheticals indicate any limitation the individual statute places on the inclusion of juvenile adjudications. 42 U.S.C. $\$ 14071$ (2000); Ala. CODE $\$ 15-20-21$ (2001); ArIZ. Rev. STAT. § 13-3821(D) (2001) (judicial discretion in applying law to juveniles); ARK. CODE ANN. § 12-12905(a)(b) (1999); CAL. PeNAL CODE $§ 290$ (d)(1) (1999) (statute only specifieally includes juveniles who had been in custody of the Department of the Youth Authority, which is a minority of the total 
sixteen states, plus the District of Columbia, are silent as to whether or not juvenile adjudications or convictions trigger registration requirements, leaving room for much judicial debate. ${ }^{99}$ Five states, Alaska, Kentucky, Louisiana, and Maine, remain silent about juvenile adjudications but specifically include juveniles convicted as adults. ${ }^{100}$ Only one state, New Mexico, specifically excludes juveniles from its statute. ${ }^{101}$ Given that juveniles and adults have had separate adjudicatory and penal systems for more than a century in the United States, the absence of a distinction under many states' Megan's Laws is a marked departure from tradition. ${ }^{102}$

Within the twenty-seven statutes that specifically include juvenile adjudications as crimes triggering registration, there is considerable variety as to what that registration entails. Just as the types of crimes, durations of registration, and extent of community notification for adult offenders vary among statutes, juveniles are treated differently by the various states.

juveniles adjudicated delinquent for sex offenses and generally tends to be the most serious offenders); Colo. Rev. Stat. § 18-3-412.5(1)(a) (1999); Del. Code AnN. 11, § 4121(a)(2) (2001); Idaho Code § 18-8401 (2002); 730 ILl. Comp. Stat. § 150/2 (1997); IND. Code ANN. § 5-2-12-4(b)(1) (2002) (registration triggered if the juvenile is over the age of fourteen); IOWA CODE $\S 692 \mathrm{~A} .2$ (4) (West Supp. 2002) (judge may waive this requirement); KAN. STAT. ANN. $\$ 22-4904(a)$ (7) (1995) (diversionary order may compel registration for a specific term for an individual juvenile); MASs. ANN. LAws ch. 6, $\S 178 \mathrm{C}$ (1999); Mich. COMP. LAWs. ANN. $\S 28.728$ (2001); MinN. STAT. $\$ 243.166$; Miss. Code ANN. $\S 45-33-25$ (Supp. 2002); MONT. CODE ANN. $\$ 41-5-1513$ (2002) (judicial discrction in applying law to juveniles); Nev. REv. STaT. ch. 179D.400 (2001); N.H. Rev. STAT. ANN. $\$$ 632A:20 (2001) (juveniles only required to submit DNA sample); N.J. STAT. ANN. § 2C:7-2 (Wcst 2001); N.C. GEN. STAT. §§ 14208.6C, 14-208.26 (1999) (judicial discretion to determine if poses danger to the community); 2001 OH. ST. $\S \S 2950.03,2952.83$ (registration triggered if the juvenile is over the age of sixteen and judicial discretion if between the ages of fourteen and sixteen); OR. REv. STAT. $\$ 181.594(B)$ (2001); R.I. GeN. LAws $\S 11-37.1-12(3)$ (D) (Supp. 2001); S.C. CODE ANN. $§ 23-3-490$ (D) (2001); S.D. CodifiEd LAws $\S 22-22-31$ (2002) (only includes juveniles fifteen years of age and older); Tex. Crim. Proc. CoDE ANN. § 62.01-2 (2002); Wash. Rev. Code § 9A.44.130(1) (2000); WIS. Stat. § 301.45 (1999) (juvenilc cxempted from registration if victim within four years of offender's age).

99. D.C. CODE $\S 22-4001$ (2001); ConN. STAT. ANN. $\$ \$ 54-250,54-251$ (West 2001) (silent for adjudications, but does state that judge may exempt offender from requirements if under nineteen at time of offense); Fla. Stat. AnN. \$944.606(1)(B) (2001); Ga. Code ANN. \$§ 42-1-12, 42-9-44.1 (1998); Haw. Rev. STAT. ANN. 846E-1(7) (1999) (does not specify that juvenile adjudications are included, but states that acts perpetrated by individuals under eighteen are not ineluded if they are crimes only because of the age of the victim); Md. Code ANN., CrIM. Proc. § 11-708(a) (2001); Mo.

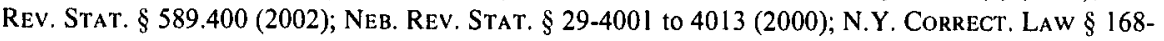
e (2001-02); N.D. Cent. Code $\$$ 54-12-22 (2001); 57 OKLa. Stat. AnN. tit. 57, § 582(c) (West Supp. 2002); 42 Pa. Cons. Stat. AnN. § 9795.1(a) (2001); Tenn. Code AnN. §§ 38-6-110, 40-39-102 (1997) (registry maintained of all people convicted of sex offenses); UTAH CODE ANN. $\$ 77-27-21.5$ (2001); VT. STat. ANn. tit. 13, §5401 (2001) (excludes offenses that are only criminal because of the age of the victim if the perpetrator is under eighteen); W. VA. CODE ANN. $\$ 15-12-1$ (2001); Wro. Stat. ANn. \$ 7-19-301 (2001). See also infra Appendix.

100. Alaska Stat. $\$ 12.63 .100$ (Michie 2000); Ky. Rev. Stat. AnN. $\$ 17.510(6)$ (1996); La. Rev. Stat. AnN. §542 (2001); 34A Me. Rev. Stat. AnN. tit. 34-A § $11203(5)$ (2001); Va. Code ANN. § 19.2-298.1(B) (2002) (statutory language unclear as to juvenile adjudications). See also infra Appendix.

101. N.M. Stat. ANN. § 29-11 A-3.8 (2000). See also infra Appendix.

102. See infra note 208 and discussion in Part II.C.2. 
While some states express no need for different requirements for adults and juveniles, others make interesting distinctions.

\section{Duration}

In very few states, the duration of registration required of juvenile offenders is different from that required of adults. In Arizona, for example, the duty to register terminates at age twenty-five, if the triggering offense resulted in juvenile adjudication of delinquency, ${ }^{103}$ whereas adults must register for ten years or life, depending on the offense. ${ }^{104}$ In Idaho, when juvenile registrants reach twenty-one, a hearing is conducted to determine whether they pose a safety threat. ${ }^{105}$ If not, they are released from the juvenile registry. If they are deemed to pose a threat, they are moved over to the adult registry and subject to its lifetime requirement. ${ }^{106}$

Some states allow both adults and juveniles to petition for termination of registration if they can show they are rehabilitated or otherwise no longer pose a threat. ${ }^{107}$ Washington differentiates the petition requirements for adults, juveniles over the age of fifteen, and juveniles under the age of fifteen. ${ }^{108}$ Adults in Washington may petition the court only after they have spent ten years in the community without being convicted of a new offense. ${ }^{109}$ Juveniles over the age of fifteen may be released from the requirement at any time if they can prove by clear and convincing evidence that future registration will not serve the purposes of the statute. ${ }^{110}$ Juveniles under the age of fifteen have the same opportunity for exemption, but their standard is only a preponderance of the evidence. ${ }^{111}$ A similar structure was adopted by the New Jersey Supreme Court in response to a recent challenge to its Megan's Law by a juvenile. ${ }^{112}$ Still, these states are exceptional. The overwhelming majority of states that require registration of juveniles do not differentiate the duration of that registration from that required of adults.

103. ARIZ. Rev. Stat. §13-3821 (2001).

104. Id.

105. IDAHO CODE $\S 18-8410$ (2002). The juvenile-registration requirement only applies to juveniles over the age of fourteen.

106. Id.

107. E.g., N.J. Stat. AnN. § 2C:7-2(f) (West 2001); Or. Rev. STAT. § 181.600 (2001).

108. Wash. Rev. CODE ANN. § 9A.44.140 (2000).

109. Id.

110. Id. The statute does not clearly state its purpose, but it appears likely that such purpose would be the prevention of future sex offenses. Thus, this requirement is probably analogous to proving future dangerousness.

111. Id.

112. In re Registrant J.G., 777 A.2d 891 (N.J. 2001), See infra discussion in Part 11.C.1.b. 


\section{Types of Offenses}

For the most part, statutes that include juveniles in their registration requirements do not make any distinctions between the kinds of acts that trigger registration by adults and those that trigger registration for juveniles. However, the federal Megan's Law makes an important distinction, which has been incorporated into the statutes of several states. These statutes state that an act by a juvenile that is criminal only because of the age of the victim does not trigger the registration requirement for juveniles. $^{113}$

Conversely, for states that do include juveniles but do not make the above exception, juveniles who are unfortunate enough to be caught and prosecuted under age-of-consent laws can be required to register for engaging in consensual sexual activity with other juveniles. ${ }^{114}$ While most young people engage in sexual activity without legal repercussions, many juveniles, particularly those closely observed by the juvenile justice system, such as dependents and delinquents in foster care or group homes, do have delinquent adjudications for consensual sexual activity. For example, an adjudication of "sexual abuse" against a sixteen-year-old boy who consensually caressed the breasts of a thirteen-year-old girl in his group home was upheld by the Supreme Court of Arizona. ${ }^{115}$ Fortunately for him, juvenile adjudications of sexual offenses cease to trigger registration requirements in Arizona once the offender reaches the age of twenty-five. ${ }^{116}$

Of course, not all juvenile adjudications of sex offenses that trigger Megan's Laws are for consensual activities. However, while many juvenile sexual interactions are clearly exploitative and even violent, others involve a degree of consent that is conceptually more fungible than allowed for by age-of-consent laws. As this Comment examines further, even juvenile sex offenses with varying degrees of force and exploitation are not well addressed by Megan's Laws and other adult models of intervention and regulation.

113. E.g., 42 U.S.C. $\$ 14071$ (a)(3)(A) (2000); HaW. REv. STAT. ANN. $\$ 846 E$ (1999); MICH. COM. Laws ANN. $\S 28.728$ (2001); Vr. STAT. ANN. tit. 13, $\S 5401$ (2001) (Violations of age-ofconscnt laws fall under this category).

114. Based on the presumption that minors are incapable of giving consent, age-of-consent laws make all sexual activity under a certain age illegal. In about half of all states, this includes sexual activity between age-peers under the age of consent, which is usually eighteen. $\ln 60 \%$ of states, lewd conduct laws make all interactive sexual activity illegal under the age of fourteen. FrankLIN ZIMRING, an american Travesty: Legal Responses to adolescent Sexual Offending (forthcoming 2004). While recognizing that minors' reduced maturity impacts their ability to give consent, this Comment does not sharc the presumption that minors are inherently incapable of consenting to sexual activity. As such, this Comment will proceed on the assumption that much of the child and adolescent sexual activity described herein, when free of force and substantial age differences, is best understood as consensual.

115. In re Pima County Juvenile Appeal No. 74802-2, 790 P.2d 723 (Ariz. 1990).

116. ARIz. Rev. STAT. §13-38211.C (2001). 


\section{Extent of Community Notification}

Several states either exempt juveniles from community notification (limiting access to their information only to law enforcement) or reduce the extent of community notification. ${ }^{117}$ For example, juveniles in Louisiana must register with law enforcement, but they do not have to publish their information in the local newspapers or go door to door to inform their neighbors of their sex-offending status as adults must. ${ }^{118}$ Juveniles adjudicated delinquent in Texas are also exempt from having their information published in newspapers; however their information may still be included in residential mailings if they were released from commitment with classifications as "sexually violent predators." 119 South Carolina spccifies that juveniles under the age of twelve are exempt from community notification, though not registration, and even then, only so long as they are not repeat offenders. ${ }^{120}$

Additionally, many states use a tiered systcm of risk assessment to determine the extent of community notification for a given sexual offender. It is worth noting that of the statutes that indicate which factors should be considered during risk assessment, many include the age of the victim with a younger victim warranting a more severe classification and more extensive notification. ${ }^{121}$ As with the triggering offenses, most states do not distinguish between adult and juvenile offenders in their risk-assessment procedures. Since minor perpetrators are more likely to have minor victims (and consensual partners are also considered victims in these situations), this uniform risk-assessment procedure weighs against young juveniles engaged in normative sexual behavior and does little to further the apparent goal of Megan's Laws' supporters-targeting dangerously violent sexual offenders. ${ }^{122}$

While it is possible that the lack of distinctions for triggering offenses and risk-assessment tools for juveniles and adults may be a legislative oversight in some states, California saw fit to amend its registration law to specifically exclude "adult" consensual sexual activities. ${ }^{123}$ It is noteworthy that the insertion of the word "adult" indicates that the California

117. La. Rev. Stat. ANN. § 542(B) (2001) (juveniles exempted from proactive notification requirement); N.H. REv. STAT. Title $62 \S 632$ A:20 (2001) (juveniles only required to submit DNA sample, whereas adult offenders face more extensive registration and notification requirements); S.C. CODE ANN. $\S 23-3-490$ (D) (2001) (juveniles exempt from notification for certain sex offenses or if under age twelve).

118. La. Rev. Stat. AnN. $\S 542$ (B) (2001).

119. Tex. Crim. Proc. Code Ann. $\$ \S 62.03(\mathrm{e}), 62.0451$ (a) (2002).

120. S.C. CODE ANN. \$ 23-3-490(D)(3) (2001).

121. E.g., N.J. STAT. ANN. § 2C:7-2 (West 2001).

122. One lower court did indicate that a consensual sexual relationship between fifteen year olds did not fall under the "heartland of cases" in the tier-classification system that required notification. In re E.1., 693 A.2d 505, 525 (N.J. Super. Ct. App. Div. 1997).

123. Cal. Penal Code $\S 290(a)(2)$ (F)(i) (1999). 
legislature at least indirectly considered the issue of juvenile consensual activity and still found it worthy of triggering registration.

\section{B. The Absence of Juvenile-Specific Discourse Surrounding Megan's Laws}

The commingling of juvenile and adult offenders within most Megan's Laws represents a marked departure from the century-old practice of separate juvenile and adult criminal justice systems. One might expect that such a significant departure would only come about with a great deal of legislative discussion establishing the sudden necessity of treating juvenile sex offenders in the same way as adult offenders, especially when breaking tradition by opening their records to public view. ${ }^{124}$ However, the legislative debates and the laws themselves reveal a notable absence of any discussion of whether the laws should apply to juveniles.

\section{1. "Findings" Sections}

Some Megan's Law statutes include "Findings" sections that summarize the legislature's reasoning behind enacting sex-offender registration and notification laws. The information is usually fairly general and does not cite empirical authority. In the statutes that apply to juveniles, information about the particular threat that juveniles pose or rationales for discontinuing the traditional practice of maintaining confidentiality for juvenile records is generally absent. For example, Arkansas makes no mention of juveniles or any specialized concerns they may pose in its single "Findings" section, even though juvenile adjudications do trigger registration and notification in the law itself. ${ }^{125}$

A more striking example of this can be found in Idaho's separate juvenile and adult sex-offender statutes. The language of the "Findings" sections in both statutes is identical, except that in one, the word "juvenile" is inserted before the words "sex offender" each time they are used. For example, the first sentence of the adult statute's "Findings" section, section 18-8302, reads: "The legislature finds that sexual offenders present a significant risk of reoffense...." "Th The first sentence of the juvenile's section, section 18-8402, reads: "The legislature finds that juvenile sex offenders present a significant risk of reoffense ...."127 Both sections go on to highlight the necessity of protecting youth from individuals who

124. Most states' juvenile codes provide that juvenile records be sealed and unavailable to the public. For example, see N.J. STAT. ANN. $§ 2 A: 4 A-60$ (West 2001). A thorough discussion of Megan's Laws' departures from the traditional juvenile justice system follows in Part II.C.

125. ARK. STAT. § 12-12-902 (1999).

126. IDAHO CODE $\$ 18-8302(2002)$.

127. Id. $\& 18-8402$. 
interact with them, without any indication of potential differences between adult and youth offenders.

However, Alabama presents a welcome exception to this pattern. Its "Legislative Findings" section notes that juveniles are more likely to respond to treatment, have shorter histories of committing sexual offenses, and are less likely to exhibit deviant patterns of sexual arousal than adult offenders. ${ }^{128}$ It still subjects juveniles adjudicated delinquent of sexual offenses to registration and notification laws, but it stresses that "certain precautions should be taken to target the juveniles that pose the more serious treats to the public." $" 129$

\section{Legislative Debate}

While the most often repeated word throughout the legislative debate of the federal Megan's Law may have been "children," the meaning of thc word as voiced by lawmakers in debates was exclusively limited to child victims of sexual offenses. Even more so than the "Findings" sections of the statutes, there was no mention in legislative debates of the child sex offenders who would be subject to community notification under federal Megan's Law. In fact, only Representative McCollum of Florida seemed to address the juvenile-offender issue when he said, "We have a lot more to do. That is especially true when it comes to the question of youth crimes ...." 130 But, when he concluded the sentence with "and crimes against those who are most vulnerable in our society: children and the elderly," one wonders what he meant by "youth crimes" after all. ${ }^{131}$ If he meant crimes committed by youth, he was the only lawmaker to mention the possibility, although the statute itself specifically included them.

California Representative Lofgren was clearly not thinking about juvenile offenders when she said, "Convictions are not secret in America. We can go down to the courthouse and find out who has been convicted."132 Indeed, this assumption by Lofgren goes to the heart of the problem with the absence of juvenile-specific discourse surrounding Megan's Laws. By granting the public access to information about juvenile sex offenders, lawmakers silently dismantled the well-entrenched tradition of not allowing anyone to find out which juveniles had been convicted. ${ }^{133}$

It is unclear whether the change was inadvertent, as statements like Lofgren's seem to suggest, or whether it was the silent sibling of a more vocal movement challenging the traditional juvenile justice system through

128. ALA. CODE $\S 15-20-21(2001)$.

129. Id.

130. See supra note 24.

131. Id.

132. 142 CoNG. REC. H4455 (daily ed. May 7, 1996) (statement of Rep. Lofgren).

133. Most states' juvenile codes provide that juvenile records be sealed and unavailable to the public. See, e.g., N.J. STAT. ANN. § 2A:4A-60 (West 2001). 
increased use of mandatory transfer to adult court and other juvenile justice "reforms," and whose views can be summed up by the election-year soundbite- "If you're old enough to do the crime, you're old enough to do the time." "134 The inclusion of juveniles under most Megan's Laws appears to be part of a nationwide trend in the last decade to treat juveniles like adult offenders through the increased use of automatic waiver of juvenile jurisdiction to the adult court. ${ }^{135}$ While juveniles who managed to remain in the juvenile-court system have been largely protected from this trend, allowing Megan's Laws to apply to them undercuts this last holdout in the war against delinquent youth. ${ }^{136}$

\section{Megan's Laws Depart from Established Juvenile-Justice Theory and Practice}

For over a hundred years, the Amcrican criminal justice system has recognized that juveniles are different from adults and should be treated as such. ${ }^{137}$ This concept has been adopted in almost every country on the globe. Indeed, Professor Franklin Zimring has called the separate juvenile justice system the most-exported aspect of the American criminal justice system. ${ }^{138}$ Its popularity is grounded in a substantial body of research showing that juvenilc crime is different from adult crime. In the words of Zimring, "growing up is the one certain cure for most juvenile crime." 139 A close look at the research shows that juvenile sex crimcs are no different in this regard. Like most crimes committed by children and adolescents, sex crimes are often committed by juveniles for different reasons than those prompting adult sex crimes. However, in applying Megan's Laws to juveniles, states have failed to take these differences into consideration.

\section{Children Are Different}

a. The Blurry Line Between Normative and Criminal Sexual Behavior

Mark Chaffin and Barbara Bonner, two psychiatrists who work with child sex offenders, reported their concern at having seen

a 10-year-old coercively interrogatcd by police without parents or attorneys present, shackled and chained, and then placed in lockup

134. See Franklin E. Zimring, The Common Thread: Diversion in the Jurisprudence of a Century of Juvenile Justice, 88 CALIF. L. Rev. 2479, 2490-91 (2000); Bob Ray Sanders, Pause before favoring prison for children, THE FORT WORTH STAR-Telegram, Oct. 18, 2002.

135. Bctween 1990 and 1996, forty states expanded the allowance for such transfers, often mandating that juveniles charged with certain crimes face adult consequences. JEFFreY FAGAN \& Franklin E. Zimring, The Changing Borders of Juvenile Justice 2 (2002) (essays exploring waiver of juvenile jurisdiction to adult court).

136. See infra Part 111. See generally Zimring, supra note 134.

137. Zimring, supra note 134.

138. $l d$.

139. Id. at 2494 . 
facilities where he was beaten and sexually assaulted by older inmates until becoming suicidal; [and] . . parents told that their 7year-old child could never return home again after two incidents of genital fondling of a 5-year-old sibling-all in the name of controlling sex offenders and all based on behavior involving single or very few incidents. ${ }^{140}$

These extreme examples highlight the unjust consequences of treating juveniles who engage in illegal sexual behaviors in the same manner as adult offenders.

As previously examined, registration and community notification for sex offenders was at least partly justified by the belief that sex offending is an innate, pathological quality resulting in exceptionally high recidivism rates. ${ }^{141}$ While this is an overbroad explanation for adult sex offenders, it is a particularly inappropriate explanation for juvenile sex offending. The established research of child and adolescent sexual behavior shows that the line between normative and criminal sexual behavior is irreparably blurred.

Over fifty years ago, Alfred Kinsey shocked the nation by revealing that what is still considered "deviant sexual behavior" was far more common than deviant. ${ }^{142}$ A well-respected entomologist, Kinsey applied his careful, detailed, scientific methodology to a massive governmentsponsored study of human sexual behavior. ${ }^{143}$ The result proved far more titillating and controversial to the public than his insect studies had been. ${ }^{144}$ Among other things, Kinsey found that childhood sexual activity was extremely common. ${ }^{145}$ Infants and toddlers demonstrated sexual response, and most children engaged in some sort of sexual play. ${ }^{146}$ More specifically, Kinsey found that $40 \%$ of preadolescent boys had engaged in heterosexual play and $60 \%$ had engaged in homosexual play, with the average age of onset for such activity being 8.8 and 9.2 years respectively. ${ }^{147}$ Kinsey's colleague found that $66 \%$ of boys in 1943 had had some heterosexual play experience by the time they were thirteen years old. ${ }^{148}$ However, far from being grateful for his thorough studies, Congress interrogated Kinsey and the Rockefeller Foundation defunded his work. The political elimate could

140. Id.

141. See supra Part I.B.2.d.

142. D'EMILIO \& FrEEDMAN, supra note 95 , at $285-86$.

143. D'EMILIO \& FREEDMAN, supra note 95, at 285-86; Rubin, supra note 68, at 284.

144. Supra note 143.

145. See generally Alfred Kinsey et al, Sexual Behavior in the Human Male 157-82 (1948) [hereinafter Kinsey et al., Human Male]; Alfred Kinsey et al., Sexual Behavior in the Human Female I01-22 (1953) [hereinafter Kinsey et al., Human Female].

I46. Kinsey et al., Human Male, supra note 145, I57-82 (sexual play includes, for example, showing, touching, attempts at intereourse, and oral contacts).

147. In the words of Kinsey, "heterosexual activity... does not occupy quite as much of the attention of the pre-adolescent boys" as does homosexual activity. Id. at I73, 610 .

148. G.V. Ramsey, The Sexual Development of Boys, 56 Aм. J. Psychol. 217, 226-27 (I943). 
not permit research dollars to go to a subject as morally depraved as normative sexual behavior. ${ }^{149}$

Although Kinsey's studies remain the most thorough on the subject to date, many modern studies have corroborated his findings that adolescent and preadolescent sexual activity is a common facet of American childhoods. A study by the University of California at Los Angeles found that $46 \%$ of children had engaged in interactive sex play (and that the percentage grew to $77 \%$ when masturbation was factored in) by age six. ${ }^{150}$ According to another study, $61 \%$ of a college-student sample reported having had some sort of sexual experience with another child by age thirteen. ${ }^{151}$ Seventeen percent of that sample admitted to engaging in sexual activity with a sibling. ${ }^{152}$ One study of 758 eighth graders in rural Maryland communities showed that $61 \%$ of the boys and $47 \%$ of the girls had had sexual intercourse. ${ }^{153}$ A more representative national study found that $40 \%$ of ninth graders and $72 \%$ of twelfth graders had had intercourse. ${ }^{154}$ The average sexually active fifteen-year-old American male has had at least four different partners, each one a potential prior offense under some Megan's Laws. ${ }^{155}$

Despite the scientific community's understanding that "[c]hildhood sex play is not psychologically harmful under ordinary circumstances and is probably a valuable psychosocial experience in developmental terms," every state in the nation has an age-of-consent law making sexual activity below a certain age a crime. ${ }^{157}$ In about half of all states, this includes sexual activity between age-peers under the age of consent, which is usually eighteen. In $60 \%$ of states, lewd-conduct laws make all sexual aetivity illegal under the age of fourteen. ${ }^{158}$ Since every state now has a minimum age well over twelve, ${ }^{159}$ according to the above research, the majority of

149. Rubin, supra note 68, at 273.

150. Paul Okami et al., Sexual Experiences in Early Childhood: 18-year longitudinal data from the UCLA family lifestyles project, 34 J. SEx REs. 339 (1997).

151. William H. Masters et. al., Human Sexuality 217 (5th ed. 1995) (citing E. Greenwald \& H. Leitenberg, Long-Term Effects of Sexual Experiences with Siblings and Nonsiblings During Childhood, 18 Archives of Sexual Behav. 389 (1989)).

152. Id. at 218 .

153. Id. at 239 (citing C.S. Alexander et. al., Early Sexual Activity Among Adolescents in Small Towns and Rural Areas: Race and Gender Patterns, 21 Fam. Plan. PerSP. 261 -66 (1989)).

154. Id. (citing Centers for Disease Control, Sexual Behavior Among High School Students-U.S. 1990, 40 MORBIDITY AND MORTALITY WKLY REP. 885-88 (1992)).

155. Id. at 240 (citing F.L. Sonenstein et al., Sexual Activity, Condom Use, and AIDS Awareness Among Adolescent Males, 21 Fam. PLAN. Persp. 152-58 (1989)).

156. Id. at 217 (citation omitted).

157. ZIMRING, supra note 114. Age-of-consent laws are based on the presumption that minors are incapable of giving consent. See supra note 114 for discussion of how this Comment does not share that presumption.

158. Id.

159. Current ages of consent in America are remarkably high when compared to other times in history. The average age of consent at the beginning of the twentieth century was ten. In some states it 
children could be guilty of a sexual offense, in addition to being irreparably harmed victims in Congress' eyes. And in many state, an age-of-consent violation triggers a Megan's Law registration requirement.

Age-of-consent laws greatly complicate the issue of adolescent sexual offending. Because the laws assume that children are incapable of giving consent, force is always implied. Certainly minors often exploit other minors' limited capacity for mature decision making. But the logic of the law deviates by holding one minor legally responsible for exploiting another minor's inability to make mature decisions about sex, even when the perceived perpetrator is just as legally incapable of consenting to sex himself. ${ }^{160}$ Unsurprisingly, in a number of studies, the majority of adolescents found guilty of sexual offenses used no force at all. ${ }^{161}$ Of the ones that did use force, only $4 \%$ to $31 \%$, depending on the study and the age of the victim, involved the use of some sort of weapon. ${ }^{162}$ The lack of a clear distinction between consensual and nonconsensual illegal sexual behavior results in an often arbitrary distinction between perpetrators and victims, with the majority of perpetrators being low-income boys, most of whom are already being observed by the juvenile justice system and thus subject to extra scrutiny. ${ }^{163}$

\section{b. In re Registrant J.G.: The Misapplication of Criminal Risk-Assessment Procedures to a Delinquent Child}

An excellent example of how this problem is magnified under Megan's Laws is found in a recent New Jersey Supremc Court decision, In

was as low as seven years of age. Today, most are eighteen. Mary E. Odem, Delinquent Daughters: Protecting and Policing adolescent Female Sexuality in the United States, I 885-I920, at 14-15 (1995).

160. The often seemingly arbitrary distinetion between perpetrator and victim is generally based on sex. According to the Supreme Court, statutory-rape laws can be sex specific (that is, only triggered by a female victim) because the perceived harm to girls is potentially greater, as they can become pregnant. Michael M. v. Superior Court of Sonoma County, 450 U.S. 464 (1981). That rationale falls short however, when one considers the public outcry when boys are victimized by men or older boys. (For a discussion of how boy victims triggered Washington's community-notification law, see discussion in Part I.A, supra.) It seems that a more accurate indicator of how culpability and harm are assigned is not the sex of the alleged victim but of the alleged perpetrator, with males routinely being assigned culpability, often regardless of age difference or consent. A more thorough examination of how harm is attributed to child and adolescent sexual activity is warranted, but it goes beyond the scope of this Comment.

161. Glen E. Davis \& Harold Lcitenberg, Adolescent Sex Offenders, 10I Psychol. BulL. 417, 419 (1987).

162. Id.

163. The Arizona boy who was found to violate parole beeause he illegally, but consensually, fondled his group home mate's breasts, is an example of the extra scrutiny on normative sexual activity that follows children in the foster care system. In re Pima County Juvenile Appeal No. 74802-2, 790 P.2d 723 (Ariz. 1990). Poor children are generally more likely to be in the foster-care system, and if arrested, they are less able to afford good representation and thercfore get second ehances in the discretion-based juvenile justice system. Barbara Bennett Woodhouse, Youthful Indiscretions: Culture, Class Status, and the Passage to Adulthood, 51 DePAul L. Rev. 743, 760 (2002). 
re Registrant J.G. ${ }^{164}$ In 1996, a juvenile plead guilty to two counts of conduct that would have been sexual assault if committed by an adult. ${ }^{165}$ J.G. was ten years old when his older sister caught him lying on top of his eight-year-old cousin with his penis exposed. ${ }^{166}$ While such an activity is common according to most research, J.G.'s act gave him a record as a firstdegree sexual offender, subject to registration for life in New Jersey.

The record of In re Registrant J.G. highlights the relative informality of juvenile sex-offense adjudications when compared to those of adults. During a probationary plea hearing, J.G. testified that he had penetrated his younger cousin. However, two separate police reports of the incident stated that penetration could not be determined. ${ }^{167}$ In addition, a medical examination of J.G.'s younger sister, whom he was also charged with sexually assaulting, found her hymen intact and no signs of sexual abuse. ${ }^{168} \mathrm{~A}$ therapist who had treated J.G. for a year testified that J.G.'s primary language was Spanish, that he was classified as multiple-handicapped and perceptually impaired, and that she believed he did not understand the meaning of the word "penetration," but rathcr thought that sex was rubbing against someone. ${ }^{169}$ While these inconsistencies probably would have derailed an adult criminal prosecution, the New Jersey Supreme Court speculated that because rehabilitory probation was the goal, a more consistent picture of J.G's culpability was not sought. ${ }^{170}$

Another incongruency between the juvenile and adult processes and outcomes exists in the way New Jersey and many other states determine which sex offenders must register. New Jersey utilizes a tier method for determining the seriousness of the sexual offense and the degree of community notification required. ${ }^{171}$ Three factors in J.G.'s case weighed toward a high-tier ranking. First, he was alleged to have committed other

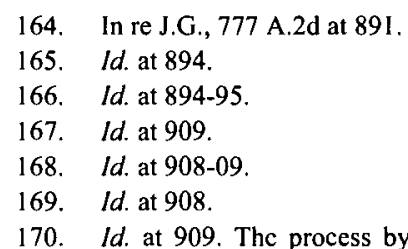
adjudications are civil in naure Kent $v$. United States, 383 U.S. $541,554-55(1966)$. The founding adjudications are civil in nature. Kent v. United States, 383 U.S. 54I, 554-55 (1966). The founding purpose of the juvenile justice system can also bc distinguished as bcing more dedicated to rehabilitation and detcrrence than the retribution-based criminal justice system. See In re Gault, 387 U.S. 1, 15-16 (1967). Although juvcnile adjudications are now subject to many of the same due-process requirements as adult procecdings, see id., the juvenile justice system still maintains significantly more discretion in matters of sentencing (called dispositions) and hearings (called adjudications) than the criminal justice system. As such, juvenile courts may adjudicatc a ehild delinquent of a crime in order to be able to provide the perceived benefits of treatment or probation, while at the same time deterring the child from the harsh sentence that would be assigned by an adult criminal court. The juvenile justice goals of intervention and deterrence are explorcd further in Part II.C.2 of this Comment.

171. N.J. Stat. ANN. § 2C:7-8 (West 2001). See generally supra Part II.A.3 (discussing ticred risk-assessment systems). 
offenses. ${ }^{172}$ Second, the victim was under the age of thirteen. Third, the alleged penetration made the offense particularly serious. However, as noted above, J.G.'s juvenile adjudication did not fully establish his culpability for either the prior offenses or the penetration. In addition, the assessment did not counterweigh the fact that someone under thirteen is much more likely to have an under thirteen "victim" than the adults for whom the factor was designed.

The New Jersey Supreme Court was concerned with the permanent impact resulting from J.G.'s adjudication and held that he did not have to register. ${ }^{173}$ It recommended revising the means of determining tier classifications to not unfairly burden juveniles. The court also noted that because it was a probationary plea hearing seeking rehabilitation rather than incarceration, as is common in juvenile adjudications, the "[Juvenile Court] may have been somewhat inattentive to its duty to elicit from J.G. a knowing and informed acknowledgment that penetration of his cousin had in fact occurred ...."174 However, the court stopped short of declaring Megan's Law unconstitutional in its application to juveniles. Rather, it held that juveniles adjudicated under the age of fourteen do not have to register past eighteen if they can prove by clear and convincing evidence that they do not pose a threat to others. ${ }^{175}$ Since neither penetration nor the existence of multiple victims was proven by clear and convincing evidence, the court held that J.G. should be reclassified to Tier 1, which limits community notification to law enforcement. ${ }^{176}$

In re Registrant J.G. provides a telling example of the relatively innocuous activities of juveniles that are being adjudicated as sexual offenses. In a study of 305 juveniles accused of committing sexual offenses, only $27 \%$ of those offenses were rape. ${ }^{177}$ Of the rest, $59 \%$ were indecent liberties, $11 \%$ exhibitionism, and $7 \%$ other noncontact offenses. ${ }^{178}$ This pattern is particularly apparent when the victim is a child. In one study, $67 \%$ of offenses committed by adolescents upon similar or older victims were rape or attempted rape (which, under age-of-consent laws, could include consensual penetration); but only $24 \%$ of offenses by the same cohort against young children involved rape, and 53\% involved indecent assaults such as touching. ${ }^{179}$ Although In re Registrant J.G. focused on

172. The second prior was the alleged offense with his sister. In re J.G., 777 A.2d at 898 . A third alleged prior offense involved exposing himself to a classmate. Id. at 898-99.

173. Id. at 911 .

174. Id. at 909 .

175. Id. at 912 .

176. Id. at 912. However, the court upheld the lower court's condition that the school that J.G. attended be notified.

177. Davis \& Leitenberg, supra note 161 , at 418 .

178. Id.

179. Id. at 419. In addition, the high numbers of rape for adolescent victims may be a reflection of the fact that age-of-consent laws consider all acts of underage penetration to be rape regardless of foree. 
penetration because it affected the tier classification in New Jersey, in many states, all sex offenses trigger extensive notification requirements. ${ }^{180}$

\section{c. The Weak Nexus Between an Identified Sex Crime and Sexual Pathology in Children and Adolescents}

Scientific research further suggests that a punitive or regulative model formulated for adults is inappropriate for juveniles. Psychological and physiological assessments of sex offenders uncover different results for juveniles than for adults. For example, while phallometric studies of adult child molesters have shown a higher degree of response to stimuli depicting children than that experienced by non-sex-offenders, juvenile offenders demonstrated a more heterogeneous response to similar phallometric tests. ${ }^{181}$ In other words, there was no measurable distinction in erectile responses between sex-offcnding and non-sex offending juveniles to "deviant" stimuli.

Similarly, a 1999 application of an assessment tool to adolescent sex offenders, which compared attractions to visual stimuli of "children and other paraphilia" to "normal attraction to females," found no correlation between the adolescents' specific attractions and known victims. ${ }^{182}$ These differences are significant given the claim that lifetime-registration requirements are justified by the innate psychopathic nature of sex offenders. ${ }^{183}$ Since there are no measurable differences in sexual preferences between juveniles adjudicated of sex-offending and other juveniles, juveniles' criminal sexual activity appears to result more from a lack of appropriate channels for sexual expression than from the kind of psychological disorder attributed to most adult offenders.

Studies that examine the social backgrounds of juvenile offenders are often no more conclusive than the psychological studies; neither successfully differentiates sexual offenders from nonsexual offenders. One study of families in which sibling incest occurred claimed to have found three parental models playing a significant role in intensifying the occurrence of

180. Given most children's awareness of intercourse and capabilities for sexual arousal, it is not surprising that some children would attempt penetration. Indeed, Kinsey found that $22 \%$ of preadolescent boys attempted "genital union" with their female partners. KINSEY ET AL., Human MALE, supra note 145, at 173. Kinsey also found that infants and toddlers are capable of crections, orgasms, and other sexual responses. Id. at 177. One could argue that whether or not such an attempt is successful is too arbitrary a factor to be determinative in assessing a child's future dangerousness.

181. John A. Hunter, Jr. \& Judith V. Becker, The Role of Deviant Sexual Arousal in Juvenile Sexual Offending, 21 Crim. Just. \& Behav. 132, 137, 142-43, 146 (1994).

182. Gilian Smith \& Lane Fischer, Assessment of Juvenile Sexual Offenders: Reliability and Validity of the Abel Assessment for Interest in Paraphilias, 11 SeXual A Buse 207, 214 (1999).

183. See Part 1.B.2.d for a further discussion of this justification. 
sibling incest. ${ }^{184}$ The models were: distant, inaccessible parents; parental stimulation of sexual climate; and family secrets and extramarital affairs. ${ }^{185}$ Within the second category, the study found that $40 \%$ had "seductive mothers" and $32 \%$ had mothers who were described as puritanical. ${ }^{186}$ It did not specify the disposition of the remaining $28 \%$ of the mothers. Thus, far from providing a consistent theory of causation, this study showed that children who were caught engaging in sibling incest could come from many different family models, whose traits often were in direct contrast with each other.

However, what the many studies do "support is the fact that nonsexual problems appear to be vastly more common than do sexual ones for these teenagers." 187 According to the Association for the Treatment of Sexual Abusers,

poor social competency skills and deficits in self-esteem can best explain sexual deviance in juveniles, rather than the paraphilic interests and psychopathic characteristics that are more common in adult offenders" and that "there is little evidence to support the assumption that the majority of juvenile sexual offenders are destined to become adult sexual offenders, or that these youths engage in acts of sexual perpetration for the same reasons as their adult counterparts. ${ }^{188}$

While one of the most documented sociological characteristics of sexually aggressive or abusive children is the existence of personal histories of sexual abuse, it is by no means alone determinative of future offending. ${ }^{189}$ One study found that $72 \%$ of children who began their sexually abusive behavior at the age of six or younger reported having been abused themselves, $42 \%$ of children who began their sexually abusive behavior between the ages of seven and eleven reported that they had been abused by others, and $35 \%$ of children who began their sexually abusive behavior at eleven or twelve acknowledged similar abuse. ${ }^{190}$ Since children who are six or younger are unlikely to be charged with a sex crime, abuse history

184. Holly Smith \& Edie Israel, Sibling Incest: A Study of the Dynamics of 25 Cases, 11 CHILD ABuse \& NeGLECT 101, 101-8 (1987). Sibling incest, like other sexual activity with and between minors, can lead to sex-offender registration and notification requirements.

185. Id.

186. Id. at 104 .

187. Mark Chaffin \& Barbara Bonner, "Don't Shoot, We're Your Children": Have We Gone Too Far in Our Response to Adolescent Sexual Abusers and Children with Sexual Behavior Problems?, 3 Child Maltreatment 314, 316.

188. Id. (quoting Ass'n for the Treatment of Sexual abusers, Position on the Effective Legal Management of JuVEniLe Sexual OfFenders (1997)).

189. Alison Gray et al., Children with Sexual Behavior Problems and Their Caregivers, 9 SexUAL Abuse: J. Res. \& Treatment 267, 270 (1997).

190. Id. (citing T.C. Johnson, Child Perpetrators-Children Who Molest Other Children, 12 Child Abuse \& NeGlect 219, 219-29 (1988)). 
appears to have diminishing relevancy in shaping the kinds of sexual activity that may trigger a registration and notification requirement.

Another study supports the argument that a history of sexual abuse need not be determinative of future abusing. The study found that "sexually abused boys, from stable families that did not blame [their child for the abuse] engaged in delinquent behaviors no more frequently than their nonabused counterparts." 191 Still another study found that while adult survivors of childhood sexual abuse generally have higher arrest rates than non-sexually abused adults, in general they are not more likely to be perpetrators of sexual abuse. ${ }^{192}$ Yet despite the lack of a determinative link between a history of abuse and future of abusing, Chaffin and Bonner note that the presumption of causation has been so embraced by policymakers that at least one state, in an eerie recasting of Megan's Laws, has proposed enacting a registration requirement for certain sexually abused children deemed a risk in order to separate them from other children in some placements. ${ }^{193}$

Some psychological and sociological studies of juvenile sex offenders claim to identify certain propensities and characteristics. However, the significance of their findings is limited because they do not include comparisons between children with varying degrees of severity of sexual offenses to each other and to nonoffending children. For example, it is hard to ascertain the significance of a finding that most offenders had been exposed to pornography by the age of seven without comparing it to the average age that nonoffending children are exposed to pornography. ${ }^{194}$ Similarly, it is doubtful that a finding that many adolescent sex offenders experience premature ejaculation would still be considered noteworthy if compared to all adolescent males. ${ }^{195}$

One study in Florida that did compare juveniles incarcerated for serious sexual crimes to juveniles incarcerated in the same facility for serious nonsexual crimes was unable to establish any consistent and significant distinctions between the groups. ${ }^{196}$ The only distinctions the study identified were believed to be more a result of Florida's commitment policies than of any characteristics particular to the two groups. ${ }^{197}$ The study, like

191. Id. at 270-71.

192. Id. at 269-70 (citing C.S. Widom, The Cycle of Violence, in National INSTITUTE of JUSTICE: RESEARCH IN BRIEF 1-6(1992)).

193. Chaffin \& Bonner, supra note 187 , at 315.

194. Edward Wieckowski et al, Deviant Sexual Behavior in Children and Young Adolescents: Frequency and Patterns, 10 Sexual Abuse: J. Res. \& Treatment 293, 301 (1998).

195. Davis \& Leitenberg, supra note 161, at 423.

196. Wendy L. Jacobs et al., Juvenile Delinquents: A Between-Group Comparison Study of Sexual and Nonsexual Offenders, 9 Sexual Abuse: J. Res. \& Treatment 201, 214 (1997).

197. Id. at 215. 
the many described above, found juvenile sexual offenders to be heterogeneous and devoid of unique characteristics. ${ }^{198}$

Although the rates vary according to the study, juvenile sex crimes differ from adult sex crimes in that a high proportion are done in groups. One 1971 study of police reports found that only $14 \%$ of police complaints of forcible rape by adolescents involved a single offender. ${ }^{199}$ All reported rapes by offenders aged ten to fourteen involved more than one offender, and $70 \%$ of rapes by adolescents over fourteen involved more than two offenders. ${ }^{200}$ Another study found that the percentage of solitary rapes committed by adults was higher than the percentage of group rapes committed by adults, thus indicating that the relative percentages of solitary and group rapes committed by juveniles were the reverse. ${ }^{201}$

The prevalence of group involvement in adolescent sexual offending is significant for two reasons. First, adolescents are more likely to engage in all criminal activity in groups. ${ }^{202}$ Second, group activity is often more the result of peer pressure and trying to impress one's friends than of individual psychosis or proclivity toward criminal behavior. ${ }^{203}$ Thus, group involvement is another indicator showing that sex offenses committed by juveniles do not represent the kind of permanent psychosis warranting lifetime registration and notification requirements. Rather, juvenile sex offenses more closely resemble the many types of delinquent activities that the juvenile justice system is designed to enable adolescents to simply outgrow.

A final indicator that juvenile sex offenders are different from adult sex offenders is that sex-reoffending rates are even lower for juvenile sex offenders than for adult sex offenders. ${ }^{204}$ As examined in this Comment, sex-offense recidivism rates for adults are only about $13 \%$, much lower than for any crime except murder. ${ }^{205}$ However, several studies of adoleseent sex offenders revealed even lower recidivism rates for juvenile sex offenses. In 1943, a six-year follow up of 108 adolescents who had originally committed sexual offenses found only two who were subsequently arrested for another sexual offense. ${ }^{206} \mathrm{~A}$ more recent study found that while $30 \%$ of juveniles who had originally committed a sexual offense were convicted of a subsequent nonsexual offense within 20 months, only $7.5 \%$

198. Id. at 214.

199. Davis \& Leitenberg, supra note 161, at 420.

200. Id; see also Franklin E. ZimRING, American Youth Violence 29 (1998) (noting that $67 \%$ of rapes committed by juveniles involved more than one offender).

201. Davis \& Leitenberg, supra note 161, at 420.

202. ZIMRING, supra note 200, at 30.

203. Id.

204. Davis \& Leitenberg, supra note 161, at 424.

205. See supra Part I.B.2.

206. Davis \& Leitenberg, supra note I61, at 424. 
were re-convicted of a sexual offense. ${ }^{207}$ These figures hardly support the proclaimed notion that high recidivism rates for sexual offenses warrant any registration or community-notification requirement for juveniles. Indeed, the fact that juvenile sex offenders who do recidivate tend to commit nonsexual offenses further indicates that a sexual disorder is not the underlying cause of their delinquent activity.

\section{Applying Megan's Laws to Juveniles is Contrary to the Established Goals of the Juvenile Justice System}

The separate juvenile justice system was established in the United States over a hundred years ago with two main goals: to divert children from the harms of the punitive criminal justice system as much as possible, and to intervene in the children's best interests when necessary. ${ }^{208}$ Applying Megan's Laws to juveniles is harmful to both of these goals.

\section{a. Megan's Laws Are Incompatible with the Diversionary Goals of the Juvenile Justice System}

In the words of Miriam Van Waters, a founder of the juvenile justice system in the United States, the separate juvenile court "came into the world to prevent children from being treated as eriminals." ${ }^{209}$ Confining children with adult criminals and treating them as such was decried by the early founders as a form of state-sponsored criminal education, leading only to corruption and continued incarceration. ${ }^{210}$ While the juvenile court has undergone various challenges and changes in its 100 -year history, its mission to divert children from the harms of incarceration has consistently remained central to the system. ${ }^{211}$ The importance of diversion was upheld in revolutionary court decisions like In re Gault and In re Winship, which applied due-process protections to juvenile proceedings in recognition of the damage that punitive consequences can inflict on young peoples' liberties and opportunities. ${ }^{212}$

In Thompson v. Oklahoma, the Supreme Court declared that the reasoning behind its holding that less culpability should attach to a crime committed by a juvenile was "too obvious to require extended explanation." 13 Professor Franklin Zimring notes that throughout the

207. Robert Prentsky et al., An Actuarial Procedure for Assessing Risk with Juvenile Sex Offenders, 12 Sexual Abuse: J. Res. \& TREatment 71, 73 (2000). In this study, the use of the word "conviction" makes it unclear whether the author is referring only to adult convictions or to juvenile adjudications as well.

208. Zimring, supra note 134, at 2480.

209. Id. at 2479 (quoting Miriam Van Waters) (footnote omitted).

210. Id.

211. See generally id.

212. Id. at 2485-89.

213. 487 U.S. 815,835 (1988). 
enormous increases in incarceration of adults in the 1990s, the nationwide levels of inearcerated juveniles aged fourteen to seventeen remained largely stagnant. ${ }^{214}$ Thus, despite enormous popular pressure to get tough on crime, juvenile courts have maintained their "determination to understand the growing child and... find ways for securing his orderly development in normal society." 215

However, many states' Megan's Laws subject children to the exact sort of debilitating consequences that the juvenile justice system was designed to eliminate. Megan's Laws mark children as sexual predators, subjecting them to stigma, prejudice, and denied opportunities. ${ }^{216}$ While dispositions requiring incarceration in some juvenile facilities can be as debilitating and brutalizing as adult sentences, juveniles are incarcerated at a lower rate than their adult counterparts. ${ }^{217}$ Moreover, protections exist, such as sealed records and more finite sentencing, which can ameliorate the long-term negative impacts of their dispositions.

In direct contrast, the states' Megan's Laws that apply indefinite or lifetime community-notification requirements for juveniles obliterate the tradition of protecting the minor's transgressions from public scrutiny. In addition, even juveniles whom the court has chosen not to subject to the harms of incarceration, such as plea bargainers and probationers, may be subject to the long-term registration and notification requirements of many states' Megan's Laws. Thus, by applying Megan's Laws to juveniles, states are dismantling the cornerstone of the diversionary juvenile justice system.

\section{b. Applying Megan's Law to Juveniles Is Contrary to the Interventionist Goals of the Juvenile Justice System}

Professor Franklin Zimring describes the second goal of the separate juvenile justice system as intervention. "A child-centered court was an opportunity to design positive programs that would simultaneously protect the community and cure the child." 218 While often in direct conflict with the diversionary goal of protecting children from damaging punitive consequences, interventionist strategies allow the court to physically redirect the juvenile from his or her delinquent path. Interventionist strategies for juvenile sexual offenders may include treatment, incarceration, or both. ${ }^{219}$

214. Zimring, supra note 134, at 2493.

215. Id. at 2485 (citing Jane Addams, Introduction, in THE CHILd, THE Clinic, AND THE CourT (Jane Addams ed., 1925)).

216. Earl-Hubbard, supra note 2, at 854-57.

217. Zimring, supra note 134 , at 2493.

218. Zimring, supra note 134 , at 2482-83.

219. Another intervention strategy is to remove potential child victims from the home if parents of juvenile sex offenders are held to not adequately protect their children from a sibling's "abuse." Judith Levine chronicles the story of a family where a single mother lost custody of both her children for two years after her eight-year-old daughter told someone at school that her nine-year-old brother had "touched her front and back." See LEvine, supra note 91, 45-67. The fact that the mother appeared 
Some Megan's Laws may require or encourage treatment for their registrants, but the use of adult models in formulating interventionist strategies for juveniles is in itself problematic and potentially counterproductive. Just as the application of laws designed for adults can be inappropriate and ineffective for juvenile offenders, treatment programs based on adult models may do more harm than good for juvenile offenders. ${ }^{220}$

Punitive or aversive treatment approaches must be considered within the context of a current political climate that exaggerates our fear of juvenile crime and energizes corresponding movements to punish children and youth as we would hardened adults (what some commentators have termed the war on children). This, combined with the emotionality and zeal surrounding sexual abuse and sex offenders as well as with the positions of power we assume in treating coerced patients under the auspices of official authority, should alert us to the potential for harming youthful patients by swatting flies with sledge hammers. ${ }^{221}$

Doctors Chaffin and Bonner describe treatment programs where teenage boys were sanctioned for looking at teenage girls and were forced to recite statement such as "I am a pedophile and am not fit to live in human society. . . I I can never be trusted. .. . [E]verything I say is a lie. . . I can never be cured." 222 They also note that while recidivism rates for treated juveniles tend to be low, no studies compare these results to those of nontreated juveniles. ${ }^{223}$ In an extensive account of abusive therapeutic institutions and incarcerations for children charged with sex offenses for exploratory behavior, Judith Levine describes how one youth committed suicide after his treatment facility would not release him after four years of his refusing to confess to an offense at age eleven that he said he did not commit. ${ }^{224}$

One study of different treatment programs for juvenile sex offenders found that the most successful programs were the least-restrictive ones that allowed the juveniles access to family support, social networks, and school. ${ }^{225}$ However, since many Megan's Laws require notification to the school the juvenile attends, the laws can turn the very structures that are most needed to help the juvenile grow out of the offending behavior into

more concerned with her son's subsequent adjudications, incarcerations, and "treatment programs" than her daughter's "victimization" was a key factor in the county's removing her daughter from her home. Id.

220. See generally Chaffin \& Bonner, supra note 187

221. Id. at 315 .

222. Id. at 315 .

223. Id.

224. Levine, supra note 91, at 45-67.

225. Lucinda A. Rasmussen, Factors Related to Recidivism Among Juvenile Sexual Offenders, 11 Sexual Abuse: J. Res. \& Treatmeint 69, 82 (1999). 
zones of hostility, isolation, and abuse. ${ }^{226}$ In addition, since poor social skills and feelings of isolation are perccived to be a common characteristic of sex offenders, stigma from the notification requirement can exacerbate these qualities. ${ }^{227}$ Thus, if the political forces that created Megan's Laws aim to prevent sexual offenses from occurring, interventionist programs and consequences for juveniles should be attuned to their unique situation as children and adolescents, and refrain from imposing debilitating "treatments" and stigmas that intcrfere with the familial and community support systems that juveniles need.

\section{III}

Suggestions for CONSTRUCTING, INTERPRETING, AND Challenging SeX-Registration and COMmunity-Notification Laws For Juveniles

Community-notification and registration requirements for juveniles are a painfully ineffective means of preventing the kinds of violent attacks suffered by children like Megan Kanka. Born out of a political pressure cooker, Megan's Laws disregard the constitutional rights ${ }^{228}$ and block the paths toward normalcy of people who often bear more resemblance to the vulnerable children the politicians claim to protect than to the monsters invoked under the media spotlight. As discussed in Part II of this Comment, this is particularly true when Megan's Laws designed for adult murderers like Jesse Timendequas are applied to juvenile sex offenders.

Part III of this Comment presents legislative and judicial approaches for mending the Megan's Laws that apply to juveniles. Because it is highly improbable that a legislature would repeal outright any sex-offender laws, given the current political climate, Part III.A presents two suggestions for legislatures wishing to include some juvenile adjudications in their statutes but still wanting to keep the statutes in line with the goals of the juvenile justice system. ${ }^{229}$ First, registration and notification requirements for juveniles should mirror the goals and procedures of the juvenile justice system, and as such, they should be designed with the distinct characteristics of children and adolescents in mind. Second, registration and notification requirements should apply only to crimes and populations with

226. R. Jeffrey Lowe, School Notification of Students' Sexual Offense Convictions: Does It Protect Our Children or Impede Quality Education?, 26 J.L. \& EDuc. 169, 175 (1997).

227. Earl-Hubbard, supra note 2, at 855-56.

228. See discussion infra Part lll.D (describing constitutional violations of Megan's Laws).

229. It is important to note that, in light of the current political climate emphasizing legislation that is "tough on crime," it may be nearly impossible to have existing laws repealed. However, it is worth noting that a recent Supreme Court decision, declaring unconstitutional the execution of the mentally retarded, considered the near political impossibility of enacting any legislation appearing soft on crime as a factor in determining the real extent of popular opinion on a given issue as being less punitive than the legislation indicates. This may be a helpful argument to invoke for future Megan's Laws challenges. See Atkins v. Virginia, 122 S. Ct. 2242, 2249 (2002). 
well-documented dangers of recidivism. Next, Part III.B suggests a method for interpreting statutes that are silent or unclear in their application to juveniles. Finally, Part III.C provides legal strategies for challenging existing registration and notification statutes that apply to juveniles.

\section{A. Tailor Registration Requirements for Juveniles to the Distinct} Characteristics of Children and Adolescents as Modeled by the Juvenile Justice System

As examined in Part II, children and adolescents often engage in criminal sexual behavior for different reasons than adults, and there is a well-established tradition of applying distinct responses to their criminality. ${ }^{230}$ Therefore, if states subject juvenile sex offenders to a registration requirement, it should be one that treats them differently from adult offenders. For example, since the juvenile justice system sets age limits on consequences and recognizes that most adolescents outgrow their delinquency, registration requirements for juveniles should have similar age limits. Arizona, which ceases to require registration for juvenile adjudications once the registrant reaches the age of twenty-five, is an example of a state that already applies an age limit to juvenile-registration requirements. ${ }^{231}$ At a minimum, states across the nation should similarly set an age limit that reflects the statutorily defined limit to incarceration for juvenile adjudications in that jurisdiction.

As examined above, juvenile sex offending is not an accurate method of predicting future offending, and thus, community notification of juvenile sex offenders is not an effective means of preventing future sex offenses. The federal Megan's Law allows states to vary the scope and subject of their community-notification requirements. ${ }^{232}$ States that do not extend or limit the application of community-notification requirements to juveniles are furthering the well-established diversionary tradition of protecting juveniles' criminal records from public scrutiny. ${ }^{233}$ In contrast, states that impose community-notification requirements for children's and adolescents' sex crimes can significantly hinder these young people's potential to grow up and out of their criminal behavior. Thus, in order to serve the juvenile court's diversionary goal of doing no harm, ${ }^{234}$ sex-offender

230. "Society has a legitimate interest in protecting a juvenile from the consequences of his criminal activity." Schall v. Martin, 467 U.S. 253, 266 (1984).

231. ARIZ. Rev. StaT. \$ 13-3821.(F) (2001).

232. 42 U.S.C. $\$ 14071$ (2000). See supra discussion in Part 1.A.

233. In general, juvenile records are kept in police department files until the juveniles reach the age of majority and their records are expunged. Dean J. Champion, The Juvenile Justice System 129 (1998). Thus, by limiting juvenile sex-offender registration information to law enforcement, states make their Megan's Laws in line with traditional juvenile justice procedures.

234. Zimring, supra note 134, at 2494-95 (describing how avoiding the harms of criminal consequences is the primary goal of the modern juvenile court). 
registration laws must not subject juveniles to community-notification requirements beyond notification to law enforcement.

As discussed above, one attempt to tailor a Megan's Law to the distinct characteristics of children occurred in Megan's home state. ${ }^{235}$ When faced with a lifetime-registration requirement for a ten-year-old offender, the New Jersey Supreme Court looked to common law and recent juvenile justice reforms to make the original Megan's Law more friendly to young offenders. ${ }^{236}$ First, the court noted that children under fourteen enjoy a rebuttable presumption of criminal incapacity under common law. ${ }^{237}$ It then linked this tradition to the recent trend in automatic-transfer laws, which generally make distinctions between juveniles under and over the age of fourteen. ${ }^{238}$ The court held that juveniles under the age of fourteen adjudicated for sex offenses do not have to register past the age of eighteen if they can prove by clear and convincing evidence that they do not pose a threat to others. ${ }^{239}$ While this solution does not address all of the problems of applying Megan's Laws to juveniles, especially for those individuals over fourteen, it did prevent further damage to at least one boy's life chances.

\section{B. Apply Registration and Community-Notification Requirements Only to Crimes and Offenders with Correspondingly High Recidivism Rates}

As presented in Part I, the rhetoric surrounding the enactment of Megan's Laws focused on the mistaken perception that sex offenders are particularly likely to recidivate. By warning the citizenry about named sex offenders, political leaders could enable parents like the Kankas to protect their children from the horrible crimes that are certain to reoccur. But as this Comment has demonstrated, that position is not supported by available research. Given that sex offenders, and juvenile sex offenders in particular, have relatively low recidivism rates, a person's status as a convicted sex offender is by itself a very poor indicator of that person's likelihood of committing future sex crimes. In addition, Megan's Laws do not identify future sex offenders who have not yet offended. Thus, even with a list of the convicted sex offenders on her block, a parent still will not have a clear picture of who actually poses a threat to her children. If sex crimes have such a low recidivism rate, it is unclear why they were singled out for a registration and community-notification requirement and why juveniles were included in them against the tradition of the separate juvenile court.

235. See supra Part I1.C.b.

236. 777 A.2d 891 (N.J. 2001).

237. Id. at 905 .

238. Id.

239. Id. at 912 . 
As examined in Part II, modern American juveniles are not free to engage in sexual activity. Americans are uniquely and fervently concerned with regulating sexual behavior, especially when it comes to young people. ${ }^{240}$ In addition, because Americans are particularly afraid of sexual deviance, community notification of sex offenses attaches an even greater stigma on the registrant than would other crimes. Since convicted sex offenders are more likely than not to never perpetuate another sexual offense, singling them out for scrutiny is illogical, inefficient, and unnecessarily damaging. This is particularly true for juveniles who are even less likely to recidivate than adults.

Part I of this Comment examined how only the most horrifically violent sexual offenses were invoked by the creators of Megan's Law. The Comment postulated that lawmakers were motivated to protect children from murders that were especially scary because they involved sex; they were not motivated by the numerous relatively minor sex crimes that fall under Megan's Laws. However, even if a registration requirement were narrowly tailored and triggered only by murder or seriously violent assaults, the only kind of crime with a lower recidivism rate than sex offenses is murder. Thus, even a notification rcquirement that was only triggered by the kinds of horrible crimes invoked during the Megan's Law debates would still not be effective in preventing those crimes because so few of these offenders pose a danger of reoffending.

Rccidivism is affected by many variables, including economic, educational, and rehabilitative factors that Megan's Laws actually exacerbate. ${ }^{241}$ Since no studies have uncovered a pure predictive relationship between any criminal behaviors and future criminality, legislators would better direct crimc-prevention funds toward nonrecidivist policies. They certainly should not penalize states that refuse to engage in such ineffective policies as community notification by withholding federal anticrime funds.

\section{Interpret Ambiguous Statutes as Excluding Juveniles or Applying Only to Adult Convictions}

Nineteen states' statutes, including that of the District of Columbia, are silent as to whether their registration and notification requirements apply to juveniles adjudicated delinquent for sex offenses. ${ }^{242}$ Some of these statutes only refer to convictions, implying that a juvenile could only be covered if convicted as an adult. At least one state court, Kansas, agreed with this analysis and held that a juvenile adjudication was not a "prior conviction" triggering the registration and community-notification 
requirements of the act for repeat offenders. ${ }^{243}$ Because of substantial difference between adult and juvenile sexual offending, as well as the differences between the procedures and outcomes of the juvenile and adult criminal justice systems, the interpretory presumption should always be that registration and community-notification statutes do not apply to juveniles adjudicated delinquent. ${ }^{244}$

\section{Constitutionally Challenge Applications of Megan's Laws to Juveniles}

[T] he theoretical and "feel-good" benefits of Megan's Law may, in the long run, be overwhelmed by the law's negative consequences. Statutes enabling, even perhaps encouraging, vigilantism and similar harms, seem utterly at odds with constitutional values. ${ }^{245}$

For the most part, Megan's Laws have been remarkably resilient to constitutional challenges. While a few courts have held that retroactive community-notification provisions are punitive and thus violate the Ex Post Facto Clause, the overall legal trend has been to find community notification regulatory and not punitive in nature. ${ }^{246}$ However, several courts have enjoined community-notification provisions under the Fourteenth Amendment, holding that states must provide minimum dueprocess protections, such as hearings and a state burden of clear-andconvincing evidence for those hearings, before infringing upon either state privacy rights or the right not to be defamed by the government. ${ }^{247}$ The courts generally recognized that the increased burden on the state was necessitated by the relatively serious liberty interest of the registrant when compared to the insubstantial value of community notification to the state. ${ }^{248}$ As stated by the Third Circuit:

243. State v. Ward, 886 P.2d 890 (Kan. 1994).

244. The juvenile justicc system has always had some mechanism where the juvenile court waives jurisdiction of certain offenders and they are transferred to adult court where they face adult consequences. FAGAN \& ZiMRING, supra note 135, at 6. Between 1990 and 1996, forty states expanded the allowance for such transfers. Id. at 2 . The question of whether or not Megan's Laws should apply to juveniles convicted as adults is beyond the scope of this Comment.

245. Paul P. v. Verniero, 170 F.3d 396, 406 (3rd Cir. 1999) (Fullam, J. concurring).

246. Walsh \& COHEN, supra note 24, at 2-5. Compare Russell v. Gregoire, 124 F.3d 1079 (9th Cir. 1997); Doe I. v. Burton, 85 F.3d 635 (9th Cir. 1996); and Artway v. Attorney Gen. of N.J., 8I F.3d 1235 (3d Cir. 1996) (holding that the community-notification requirements were not punitive), with Doe I. v. Otte, 259 F.3d 979 (9th Cir. 2001) (holding that Alaska's provisions were punitive). The fact that at least one state's Megan's Law was found to constitute punishment in 200I in a circuit that had previously found another state's Megan's Law not to be punishment indicates that the issue is not yet moot. See Otte, 259 F.3d at 979 . The Otte court distinguished Alaska's provisions, which made all information about all sex offenders available to the public on the Internet, from the less extensive community notification provisions of Washington, which had been found not to constitute punishment.

247. Doe v. Dept. of Pub. Safety ex rel. Lee, 27I F.3d 38 (2d Cir. 200I); E.B. v. Verniero, I19 F.3d 1077 (3d Cir. 1997); Fullmer v. Mich. Dept. of State Police, 207 F. Supp. 2d 650 (E.D. Mich. 2002); Doe No. I v. Williams, I67 F. Supp. 2d 45 (D.D.C. 2001); Doe v. Pryor, 61 F. Supp. 2d I224, 1231 (M.D. Ala. 1999); Doe v. Pataki, 3 F. Supp. 2d 456 (S.D.N.Y. I998).

248. E.B. v. Verniero, 119 F.3d I077 (3d Cir. 1997). 
An erroneous underestimation of an individual's dangerousness will not necessarily result in harm to protected groups.... On the other hand, an overestimation of an individual's dangerousness will lead to immediate and irreparable harm to the offender: his conviction becomes public, he is officially recorded as being a danger to the community, and the veil of relative anonymity behind which he might have existed disappears. ${ }^{249}$

Because juvenile proceedings have different due-process standards than adult proceedings, juveniles could raise a Fourteenth Amendment challenge claiming that their standards of due process are not adequate to address a potential status change and repercussions that extend into adulthood. In response to a juvenile's claim that, if subjected to adult sanctions under a Megan's Law, he should get adult due process, a Minnesota court held that the difference in due process met fundamental-fairness standards, but suggested that the legislature rethink the inclusion of juveniles under the statute. ${ }^{250}$ This approach appears to have foreshadowed the New Jersey Supreme Court's acknowledgment of the dangers of applying adult, lifetime repercussions to juvenile adjudications. ${ }^{251}$

One compelling argument for juveniles is to claim that they have a protected liberty or property interest in the confidentiality of their records. Some federal courts, including the Ninth Circuit, have held that offenders have no right to privacy in information already available to the public. ${ }^{252}$ However, most states' juvenile codes provide that juvenile records are not available to the public. ${ }^{253}$ Thus, a juvenile offender in the Ninth Circuit would have a strong argument that she has a privacy interest in keeping her adjudications safe from public scrutiny.

249. Id. at 1110 .

250. In re C.D.N., 559 N.W.2d 431 (Minn. 1997).

251. For a discussion of In re Registrant J.G., see supra Part 11.C.1.b.

252. E.g., Russell, 124 F.3d at 1079; Doe v. Kelley, 961 F. Supp. 1105 (W.D. Mich. 1997). However, some courts appear to be more receptive to an adult privacy challenge to Megan's Laws. A more recent Ninth Circuit decision indicated its receptiveness to a privacy challenge to Alaska's community-notification provisions, which it noted were more invasive than the Washington provisions that had escaped a privacy challenge in Russell. Otte, 259 F.3d at $995 \mathrm{n} .15$. In addition, the Third Circuit has held New Jersey's community-notification provisions to violate its state right to privacy. Verniero, 119 F.3d at 1106 . Finally, in holding that its community-notification provisions did not violate privacy rights, a California district court at least partially based its reasoning on the fact that CAL. Penal Cone $\S 290.4$ (West 1999) (containing CD-ROM and telephone-notification provisions) was not challengcd, probably because it was in a separate statute section and was inadvertently left out of the claim. The court reasoned that this unchallenged provision already made an offender's information available to the public, so registrants did not have a privacy interest in their information being distributed through the law-enforcement discretion of another provision of the code. Byron M. $\mathrm{v}$. City of Whittier, 46 F. Supp. 2d 1032, 1036 (C.D. Cal. 1998). Thus, even adults in California may still be able to successfully challenge the community-notification requirement on privacy grounds so long as they address all of the state's notification requirements in their challenge.

253. See, e.g., N.J. STAT. ANN. § 2A:4A-60 (West 2001). 
While some courts have ruled that Megan's Laws supersede states' juvenile-code restrictions because Megan's Laws were enacted later or were more specific, ${ }^{254}$ these courts are dodging a chicken-and-egg problem. For example, if the Ninth Circuit is arguing that the registrant has no privacy interest because an offender's information was never private to begin with, a juvenile could rightly argue that she does have an established privacy interest that was statutorily protected prior to the enactment of Megan's Law. Thus, juveniles could challenge the existence of a community-notification requirement as violating their longstanding expectation of privacy in their records. Indeed, one court specified that the issue of confidentiality was immaterial in that particular jurisdiction, mainly because disclosure of juvenile information under its Megan's Law was limited to law enforcement, thus implying that if notification went beyond law enforcement, it would violate juveniles' expectation of privacy. ${ }^{255}$ One federal court held that juveniles have a particularized liberty interest in the established policy of "setting aside" their criminal records. ${ }^{256}$ However, the court stopped short of finding community notification to be impermissibly violative of this particularized liberty interest for all juveniles. ${ }^{257}$ Rather, it held that procedures to determine who would be subject to notification must consider juveniles' heightened liberty interests. ${ }^{258}$

Another potential due-process argument is that children have a constitutionally protected interest in not being wrongly classified as dangerous sexual predators. Several federal courts at both the appellate and trial level have enjoined some states' Megan's Laws for adults and juveniles, holding that the notification methods constituted government defamation by falsely labeling all prior sex offenders as potential future predators without sufficient due process to determine an individual's actual future dangerousness. ${ }^{259}$ These courts applied the Supreme Court's Paul v. Davis "plus" test, whieh requires a defamatory statement by the government plus a burden or change in the plaintiff's legal status in order to find governmental defamation. ${ }^{260}$ The courts found the first prong satisfied because inclusion in community notification implied that an individual posed a threat. However, since previous conduct was not a guarantee of future dangerousness,

254. Doe v. Attorney Gen., 680 N.E.2d 92 (Mass. 1997); In re B.G., 674 A.2d 178, 184-85 (N.J. Super. Ct. App. Div, 1996).

255. In re Appeal in Maricopa County Juvenile Action No. JV-132744, 933 P.2d 1248 (Ariz. Ct. App. 1996).

256. Doe No. I v. Williams, 167 F. Supp. 2d 45, 64 (D.D.C. 2001).

257. Id.

258. Id.

259. E.g., Doe v. Dept. of Pub. Safety ex rel. Lee, 271 F.3d 38 (2d Cir. 2001); Verniero, 119 F.3d at 1077; Fullmer v. Mich. Dept. of State Policc, 207 F. Supp. 2d 650 (E.D. Mich. 2002); Doe No. 1 v. Williams, 167 F. Supp. $2 d 45$ (D.D.C. 2001); Doe v. Pryor, 61 F. Supp. 2d 1224, 1231 (M.D. Ala. 1999).

260. See supra note 259 . 
subjecting individuals to community notification only on the basis of a past conviction and without an individualized determination of future dangerousness constituted defamation. ${ }^{261}$ They then found that the individual's status was altered by the registration requirements which subjected individuals to felony prosecution if they failed to register. ${ }^{262}$

This governmental-defamation argument could be an especially powerful tool for juveniles because they have an even lower recidivism rate than do adults, and thus, the label of dangerous predator is especially false and defamatory. In addition, juveniles' legal status is especially altered by Megan's Laws because juvenile sex offenders face a longer and more public status change than do juvenile offenders adjudicated for other crimes.

Juveniles may also have a liberty interest in avoiding the stateinduccd harms to their health and well-being that result from the codification of the state's disapproval of youthful sexual activity in many states' Megan's Laws. In his concurrence in Carey v. Population Services, Justice Stevens analogized New York's prohibition of a minor's access to prophylactics to the state's "dramatiz[ing] its disapproval of motorcycles by forbidding the use of safety helmets." 263 Stevens posited that the government-mandated harm of "infecting the promiscuous child ... [is] ... appropriately characterized as a deprivation of liberty without duc process of law." ${ }^{264}$ As observed by both the Justices in Carey and the research cited above, juvenilcs will engage in sexual activity regardless of government prohibitions. However, community notification can deny a child the opportunity to grow up normally by subjecting him or her to false labels of sexual dysfunction, ostracism, reduced life chances, and harassment. ${ }^{265}$ Further, the public label of abhorrent sex offender can only exacerbate the isolation and social inadequacies that have been linked to the relatively few individuals who do pose a risk of chronic sex offending. While the state is free to express its disproval of child and adolescent sexual activity and attempt to prevent it, it should not do so through ineffective methods that actually exacerbate the kinds of harms to juveniles' health and well-being that it is trying to prevent.

Despite the overwhelming scientific evidence and established legal tradition that juvenilc scx offenders should bc treated differently from adult

\footnotetext{
261. Id.

262. Id.

263. 431 U.S. 678, 715 (1977) (Stevens, J., concurring).

264. Id. at 716 .

265. In countless incidents, community notification has led to community vigilantism. Examples listed by one federal court includc, among many others, thc loss of employment, threats of and actual violence, and public harassment of family mcmbers and children. See Doe v. Pataki, 940 F. Supp. 603, 608-10 (S.D.N.Y. 1996). Even when not facing such open hostility, a registrant must navigate the morc masked, but still palpable, hostility of neighbors, school personnel, classmates, and potential employers on a regular basis. The damage such hostility can wreak on a young person's opportunities to grow into a competent and healthy adult is undoubtedly substantial.
} 
sex offenders, Congress and many state legislatures irrationally have lumped the two together under Megan's Laws, generally without any justification. In so doing, they are arbitrarily forcing thousands of children to face an utterly false lifetime classification as dangerous perverts. The interest in not being misclassified in such a fundamental and permanent way rises at least to the level of the many other liberty interests protected by the Due Process Clause.

\section{CONCLUSION}

Children who commit sexual offenses generally have the same vulnerabilities and are in the same need of protection as the child victims whom the proponents of Megan's Laws claim to protect. But Megan's Laws have the unique propensity to gravely harm some children in the hope of protecting an unknown few. Many child sex offenders are victims of sexual abuse themselves. Many more engage in common sexual behavior, sometimes healthy, sometimes inappropriate, that they will most likely learn to manage. Megan's Laws stigmatize and isolate these children, limiting their opportunities for normal growth and exacerbating the kinds of vulnerabilities that lead to future criminality, both sexual and nonsexual. When lawmakers vociferously declared that children were in more need of protection than convicted sex offenders, they never indicated that some of the sex offenders they were targeting were themselves vulnerable children.

The American criminal justice system has long been a battleground between the warring goals of punitive retribution and utilitarian crime prevention. In many aspects, retribution is winning to such an extent that payments for crimes are exacted throughout the offender's life. Mandatory minimums have exponentially increased time behind bars for certain drug violations. In many states, felons forfeit their political rights even upon release. And more states are enacting automatic transfer to adult court for some juvenile offenses. Juveniles fortunate enough to remain in the juvenile justice system have generally been protected from these increased consequences. Now, Megan's Laws have dismantled this last protective holdout. By applying Megan's Laws to juvenile adjudications, states throw out a century of juvenile justice jurisprudence and scholarship to protect an even older tradition of fear about childhood sexuality. In so doing, lawmakers perpetrate irreparable damage to the very children they claim to protect. 


\section{APPENDIX \\ The Treatment of Juvenile Adjudications in Each State's Megan's Law}

\begin{tabular}{|l|l|l|l|l|l|l|}
\hline & $\begin{array}{l}\text { Separate } \\
\text { statute/req }\end{array}$ & $\begin{array}{l}\text { Specifically } \\
\text { included }^{267}\end{array}$ & $\begin{array}{l}\text { Specifically } \\
\text { excluded }^{268}\end{array}$ & $\begin{array}{l}\text { Silent as to } \\
\text { juvenile ad- } \\
\text { judication }\end{array}$ & $\begin{array}{l}\text { Specifically } \\
\text { includes } \\
\text { juveniles } \\
\text { convicted as } \\
\text { adults }{ }^{270}\end{array}$ & $\begin{array}{l}\text { Juveniles } \\
\text { subject to } \\
\text { community } \\
\text { notifica- } \\
\text { tion? } \text { ? }^{271}\end{array}$ \\
\hline Fed & & $\mathrm{X}^{272}$ & & & & yes \\
\hline $\mathrm{AL}$ & & $\mathrm{X}^{273}$ & & & & yes \\
\hline $\mathrm{AK}$ & & & & $\mathrm{X}$ & $\mathrm{X}$ & \\
\hline $\mathrm{AZ}$ & $\mathrm{X}^{274}$ & $\mathrm{X}$ & & & & unclear $^{275}$ \\
\hline $\mathrm{AR}$ & & $\mathrm{X}$ & & & & yes \\
\hline $\mathrm{CA}$ & $\mathrm{X}^{276}$ & $\mathrm{X}$ & & & & unclear ${ }^{277}$ \\
\hline $\mathrm{CO}$ & $\mathrm{X}^{278}$ & $\mathrm{X}$ & & & & yes \\
\hline $\mathrm{CT}$ & & & & $\mathrm{X}$ & & \\
\hline $\mathrm{DE}$ & & $\mathrm{X}$ & & & & yes \\
\hline $\mathrm{DC}$ & & & & $\mathrm{X}$ & & \\
\hline $\mathrm{FL}$ & & & & $\mathrm{X}$ & & \\
\hline $\mathrm{GA}$ & & & & $\mathrm{X}$ & & \\
\hline $\mathrm{H} 1$ & & & & $\mathrm{X}$ & & yes \\
\hline $\mathrm{ID}$ & & $\mathrm{X}$ & & & & limited \\
\hline
\end{tabular}

266. Juveniles have separate statute or separate requirements from adults.

267. See supra note 98 (list of statutes).

268. See supra note 101 (list of statutes).

269. See supra note $99 \& 100$ (list of statutes). Includes statutes that only refer to "convictions."

270. See supra note 100 (list of statutes).

271. "Yes" may mean the act is silent as to whether juvenile registrants are specifically subject to notification.

272. This excludes "conduct which is criminal due solely to age of victim." 42 U.S.C. $14071(\mathrm{a})(3)(\mathrm{A})(2000)$.

273. An act requiring registration and treatment for juvenilcs was signcd by the code commissioner but not yet codified by the legislature.

274. Juveniles only required to register until age twenty-five.

275. The community-notification section states "conviction," but it does not include adjudication. It is thus possible that registered juveniles are spared community notification unless convicted as adults, but this is not specified. AR1z. Rev. Stat. \& 13-3825 (2001).

276. Statute only specifically includes juveniles who had been in custody of the Departinent of Youth Authority, which is a minority of the total juveniles adjudicated delinquent for sex offenses, and generally tends to be the most serious offenders.

277. Specifies "conviction" in community-notification provisions; no mention of adjudications except for prior offense. CaL. Penal Code $§ \S 290(m)-(r), 290.4$ (1999).

278. Different penalties for failing to register.

279. Does not specifically say juvenile adjudications are included, but does say that acts perpetrated by individuals under the age of eighteen are not covered if they are only crimes based on the age of the victim.

280. Only applies to juveniles adjudicated delinquent ages fourteen and over. 


\begin{tabular}{|c|c|c|c|c|c|c|}
\hline & $\begin{array}{l}\text { Separate } \\
\text { statute/req }\end{array}$ & $\begin{array}{l}\text { Specifically } \\
\text { included }\end{array}$ & $\begin{array}{l}\text { Specifically } \\
\text { excluded }\end{array}$ & $\begin{array}{l}\text { Silent as to } \\
\text { juvenile ad- } \\
\text { judication }\end{array}$ & $\begin{array}{l}\text { Spccifically } \\
\text { includes } \\
\text { juveniles } \\
\text { convicted as } \\
\text { adults } \\
\end{array}$ & $\begin{array}{l}\text { Juveniles } \\
\text { subjcct to } \\
\text { community } \\
\text { notification? }\end{array}$ \\
\hline $1 \mathrm{~L}$ & & $\mathrm{x}$ & & & & unclear $^{281}$ \\
\hline IN & & $\mathrm{X}^{282}$ & & & & yes \\
\hline IA & $\mathrm{X}^{283}$ & $\mathrm{X}$ & & & & yes \\
\hline $\mathrm{KA}$ & $\mathrm{X}^{284}$ & $x$ & & & & \\
\hline $\mathrm{KY}$ & & & & & $\mathrm{X}^{285}$ & yes \\
\hline LA & $\mathrm{X}^{286}$ & & & $\mathrm{X}$ & $\mathrm{X}$ & no \\
\hline $\mathrm{ME}$ & & & & & $X$ & \\
\hline $\mathrm{MD}$ & & & & $\mathrm{X}$ & & \\
\hline $\mathrm{MA}$ & & $\mathrm{X}$ & & & & yes \\
\hline MI & & $\mathrm{X}^{287}$ & & & & unclear $^{288}$ \\
\hline $\mathrm{MN}$ & & $\mathrm{X}$ & & & & unclear $^{289}$ \\
\hline $\mathrm{MS}$ & $X^{290}$ & $\mathrm{X}$ & & & & yes \\
\hline $\mathrm{MO}$ & & & & $\mathrm{X}$ & & \\
\hline MT & $X^{291}$ & $\mathrm{X}$ & & & & unclear \\
\hline $\mathrm{NE}$ & & & & $\mathrm{X}$ & & \\
\hline NV & $\mathrm{X}$ & $\mathrm{X}$ & & & & yes $^{292}$ \\
\hline $\mathrm{NH}$ & $X^{293}$ & $x$ & & & & no \\
\hline
\end{tabular}

281. "Juvenile sex offenders" and "sex offenders" are defined separately. 730 ILl. Comp. STAT. $\S \S 150 / 2,152 / 105$ (I997). The community-notification provisions cover all "sex offenders" with certain offenses or adjudications. The community-notification provisions do not address juvenile sex offenders directly, except in the definitions section. 730 ILL. Comp. STAT. § 152/120 (1997). Thus, it appears that "juvenile sex offenders" are excluded from the community-notification provisions as they are defined separately from "sex offenders," but it is not completely clear, especially because the provisions include "adjudications."

282. Applies if over the age of thirtecn.

283. The application of registration requirements is up to juvenile-court discretion for individual juveniles.

284. While State v. Ward, 886 P.2d 890 (1994), held that juvenile adjudication was not a conviction for purposes of the act, the 1995 law allows diversionary orders to compel registration for some offenders.

285. Same limitation as the federal statute. See supra note 272.

286. Juveniles excluded from personal, proactive notification requirement, but still must register and are subject to some notification.

287. Excludes statutory rape.

288. Juvenile dispositions for certain violations are included "after the individual becomes 18 years of age." Мiсн. СОм. LAW $\S 28.728$ (2001).

289. Community-notification provision only specifies convictions, while registration section includes adjudications. MiNN. STAT. $\S \S 244.052,243.166$.

290. Requires a prior adjudication.

291. Up to juvenile-court discretion.

292. Special provision says juvenile guidelines should be established in line with adult guidelines as much as is practicable.

293. Only requircs DNA sample from juvenile, no community notification. 


\begin{tabular}{|c|c|c|c|c|c|c|}
\hline & $\begin{array}{l}\text { Separate } \\
\text { statute/req }\end{array}$ & $\begin{array}{l}\text { Specifically } \\
\text { included }\end{array}$ & $\begin{array}{l}\text { Specifically } \\
\text { excluded }\end{array}$ & $\begin{array}{l}\text { Silent as to } \\
\text { juvenile ad- } \\
\text { judication }\end{array}$ & $\begin{array}{l}\text { Specifically } \\
\text { includes } \\
\text { juveniles } \\
\text { eonvicted as } \\
\text { adults }\end{array}$ & $\begin{array}{l}\text { Juveniles } \\
\text { subject to } \\
\text { community } \\
\text { notification? }\end{array}$ \\
\hline NJ & & $X$ & & & & yes \\
\hline NM & & & $\mathrm{X}$ & & & \\
\hline NY & & & & $x$ & & \\
\hline $\mathrm{NC}$ & $X^{294}$ & $x$ & & & $\mathrm{X}$ & yes \\
\hline ND & & & & $X$ & & \\
\hline $\mathrm{OH}$ & $\mathrm{X}$ & $\mathrm{X}$ & & & & yes $^{295}$ \\
\hline $\mathrm{OK}$ & & & & $x$ & & \\
\hline OR & & $\mathrm{X}$ & & & & yes $^{296}$ \\
\hline PA & & & & $\mathrm{X}$ & & \\
\hline $\mathrm{RI}$ & & $X$ & & & & yes \\
\hline $\mathrm{SC}$ & $X^{297}$ & $\mathrm{X}$ & & & & yes \\
\hline SD & & $X^{298}$ & & & & yes $^{299}$ \\
\hline $\mathrm{TN}$ & & & & $x$ & & \\
\hline $\mathrm{TX}$ & $X^{300}$ & $\mathrm{X}$ & & & & limited $^{301}$ \\
\hline UT & & & & $X$ & & \\
\hline $\mathrm{VT}$ & & & & $\mathrm{X}^{302}$ & & yes \\
\hline VA & & & & $\mathrm{X}$ & & yes \\
\hline WA & & $\mathrm{X}$ & & & & yes \\
\hline WV & & & & $X$ & & \\
\hline WI & $X^{303}$ & $X$ & & & & yes \\
\hline$W Y$ & & & & $X$ & & \\
\hline
\end{tabular}

294. Court discretion to determine if juvenile poses a danger to the eommunity.

295. Special provisions for juvenile notification.

296. Interesting provision that one may not release information if it interferes with treatment.

297. Specifie provision for juveniles delineating which acts get which kinds of community notifieation. Persons under twelve havc to register and are subject to community notifieation if they have a prior. Registration is for life.

298. Only applies to juveniles aged fifteen or older.

299. Registry is a public reeord-no other description of community notification.

300. Special hearing may excuse juveniles from rcgistration.

301. Juveniles under age seventeen are excluded from being published in newspapers, but they appear to be included in notification via residential mailings.

302. Same limitation as fcderal statute. See supra note 272.

303. Juvenile exempted from registration if victim within four years of offender's age. 